\title{
Assessment by Self-Organizing Maps of element-release from sediments in contact with acidified seawater in laboratory leaching test conditions
}

\author{
I. Muñoz ${ }^{(1)(*)}$, M.C. Martín-Torre ${ }^{(1)}$, B. Galán ${ }^{(1)}$, J.R. Viguri ${ }^{(1)}$ \\ (1) GER Green Engineering and Resources Group. Department of Chemistry and Process \& \\ Resource Engineering, ETSIIT, University of Cantabria, Spain. \\ (*) Corresponding author: (942)201583, munozi@unican.es
}

\begin{abstract}
Carbon capture and storage (CCS) is gaining interest as a significant global option to reduce emissions of $\mathrm{CO}_{2}$. CCS development requires an assessment of the potential risks associated with $\mathrm{CO}_{2}$ leakages from storage sites. Laboratory leaching tests have proved to be a useful tool to study the potential mobilization of metals from contaminated sediment in a decreased-pH environment that mimics such a leakage event. This work employs a Self-Organizing Map (SOM) tool to interpret and analyze the release of Dissolved Organic Carbon (DOC), As, $\mathrm{Cd}, \mathrm{Cr}, \mathrm{Cu}, \mathrm{Ni}, \mathrm{Pb}$ and $\mathrm{Zn}$ from equilibrium, column and $\mathrm{pH}$-dependent leaching tests. In these tests, acidified seawater is used for simulating different $\mathrm{CO}_{2}$ leakage scenarios. Classification was carried out detailing the mobilization of contaminants for environments of varying $\mathrm{pH}$, liquid-to-solid ratio and type of contact of the laboratory leaching tests. Component planes in the SOMs allow visualization of the results and the determination of the worst-case of element-release. The $\mathrm{pH}$-dependent leaching test with initial addition of either base or acid was found to mobilize the highest concentrations of metals.
\end{abstract}

KEY WORDS: Metal-release assessment, Carbon capture and storage, Self-Organizing Maps, Leaching tests, Sediment acidification

\section{INTRODUCTION}

Emissions of carbon dioxide $\left(\mathrm{CO}_{2}\right)$ have been identified as the key factor responsible for climate change and effective measures and technologies need to be implemented to decrease these emissions (IPCC 2014). Carbon capture and storage (CCS) using geological sequestration in on- and offshore formations is a promising measure being considered worldwide to allow the continued use of fossil-fuels while preventing the associated emissions of $\mathrm{CO}_{2}$ from reaching the atmosphere (Corsten et al. 2013; Koornneef et al. 2012).

The CCS process consists of the capture of $\mathrm{CO}_{2}$ from an industrial emitter, its transportation to a storage site in gas or liquid phase and its storage or sequestration in stable geological formations. Although $\mathrm{CO}_{2}$ is injected into deep storage formations, there is a risk of $\mathrm{CO}_{2}$ leakage from storage sites to the near-surface 
environment and the effects of such a leakage need to be properly addressed. For offshore storage sites, an impact assessment of such leakages on the surrounding environment should include the mobilization of substances from caprock formations, marshes and sediment by the resulting seawater acidification (Payán et al. 2012a). The European Union (EU) Directive on the geological storage of $\mathrm{CO}_{2}$ (DOL 2009), that is based on the London Protocol and the OSPAR Convention (OSPAR 2007; RAMF 2006), establishes the framework to determine the risk assessment for and management of $\mathrm{CO}_{2}$ storage. Mobilization of metals in an acidified environment is a subject of concern in the CCS Directive as well as in the Marine Strategy Framework Directive (DOL 2008), both of which are focused on the marine environment.

In recent years, several studies have assessed the risks and potential impacts of CCS technology using a range of approaches. A diverse set of tools has been applied to the various technology stages in the CCS process with life-cycle assessment (LCA) and a variety of modeling methods often used (Table 1). While current LCA studies on CCS focus on different technologies, timeframes and aspects treated (Corsten et al. 2013), most storage analyses do not account for potential $\mathrm{CO}_{2}$ leakages; considering them to be negligible, unlikely to occur, or zero (Table 1). Where $\mathrm{CO}_{2}$ leakages during the storage stage are considered, the assessment is carried out according to degradation in aquifer properties and/or leakage rates, but is not related to the metal mobilization.

Modeling techniques, such as those detailed in Table 1, can be used when predicting the spatial and temporal evolution of injected $\mathrm{CO}_{2}$ and to identify changes in water quality that may ensue. The results from the modeling techniques may also help to develop possible mitigation strategies if leaks were to occur at storage sites. Predictive models have been used to estimate the risk of $\mathrm{CO}_{2}$ leakages from storage sites, analyzing changes to the storage formation, the probability of leakage occurrence and the leakage ratio (Table 1). Birkholzer et al. (2008) show different possible geochemical reactions-such as mineral dissolution and metal mobilization - because of $\mathrm{CO}_{2}$ leakage during storage. Despite the promise that modeling offers, field and laboratory studies are still required to decrease uncertainties in model assumptions and to validate model findings.

To complement LCA and modeling studies, analysis of natural and industrial analogues have been conducted both in-situ and in laboratory experiments to develop understanding of the risk posed by $\mathrm{CO}_{2}$ leakages. Laboratory leaching tests have been widely used for studying the potential mobilization of elements in a decreased-pH environment because of ocean acidification and $\mathrm{CO}_{2}$ leakages during the $\mathrm{CCS}$ 
storage stage (Martín-Torre et al. 2014, 2015 a, b). Equilibrium, column, core flow, sequential, pHdependent and multiphase leaching tests have been used, among others, to evaluate the mechanisms and the levels of metal mobilization from sediments exposed to acidified seawater (De Orte et al. 2014; Varadharajan et al. 2013; Payán et al. 2012 a, b; Ardelan et al. 2012, 2010, 2009; Ellis et al. 2011; Carey et al. 2009 ).

The use of an assortment of leaching tests allows for the assessment of metals' behavior under a wide range of variables, such as acidification, time of contact, and hydrological conditions. Thereby, the metal-release in different scenarios of sediment acidification can be tested. Equilibrium tests simulate the re-suspension of sediments in acidified seawater due to $\mathrm{CO}_{2}$ gas bubbling or dredging operations; column leaching tests simulate advective flow of acidified seawater arising from rapid fracture deterioration in caprock; and $\mathrm{pH}-$ dependent leaching tests simulate scenarios of constant acidification (Payán et al. 2012 a, b; Martín-Torre et al., 2015 a).

Classical multivariate statistical techniques, such as Principal Component Analysis and Hierarchical Component Analysis, have been commonly used to assess and classify sediment quality according to their contamination and metal-release behavior under different conditions using a variety of physico-chemical data (Khosrovyan et al. 2015; Moukhchan et al. 2013; Choueri et al. 2009; Cesar et al. 2007; MoralesCaselles et al. 2007; Simeonov et al. 2007). Self-Organizing Maps (SOMs) and an artificial neural network with unsupervised learning have so far been used in a more limited way as an alternative to classical multivariate statistical techniques to assess sediment quality (see for example: Tsakovski et al. 2009;Álvarez-Guerra et al. 2008; Arias et al. 2008).

The main objective of this work is the use of a SOM tool to analyze element-release data from contaminated sediment under different laboratory leaching tests that simulate conditions of $\mathrm{CO}_{2}$ leakages from a CCS storage site. The work is divided into equilibrium and column tests with $\mathrm{CO}_{2}$ acidified seawater, and $\mathrm{pH}$-dependent leaching tests with nitric acid $\left(\mathrm{HNO}_{3}\right)$ acidified seawater. The proposed methodology permits the integration of element-release concentrations obtained during experiments of varying $\mathrm{pH}$, liquid-to-solid ratios $(\mathrm{L} / \mathrm{S})$ and type of contact, which together simulate different $\mathrm{CO}_{2}$ leakage scenarios.

\section{MATERIALS AND METHODS}




\section{Sampling site and data sets}

The data used in this study are originated from four different leaching tests carried out under different conditions. These leaching tests have been applied to sediment sampled in the Suances estuary (Northern Spain), a narrow and shallow mesotidal estuary, which has been identified as a potential CCS storage site. The sediment contains significant concentrations of metals and organic pollutants that are derived from different activities upstream of the estuary. A detailed description of the studied area and sediment characterization is shown in Martín-Torre et al. 2015 a.

The sediment used for experimental assays was sieved through a $2 \mathrm{~mm}$ mesh to remove the gravel fraction, homogenized and frozen in $3 \mathrm{~kg}$ plastic bags until use. The used seawater $(\mathrm{pH}=8.02 \pm 0.076$ and $35 \%$ salinity) was supplied by the Maritime Museum of Cantabria in Santander, filtered through $0.45 \mu \mathrm{m}$ and it is used within the next 24 hours. The seawater is chemically analyzed by the same procedure of the sample leachates of each leaching test. Concentrations of $\mathrm{As}, \mathrm{Cd}$ and $\mathrm{Zn}$ of the used seawater, considered in all data analysis, are $2.91 \pm 0.858 ; 0.528 \pm 0.653$ and $13.788 \pm 7.506$, respectively. Concentrations of $\mathrm{Cr}, \mathrm{Cu}, \mathrm{Ni}$ and $\mathrm{Pb}$ are below the detection limit of the equipment (4, 2, 2 and $0.4 \mu \mathrm{g} / 1$, respectively).

Equilibrium leaching tests were performed at the liquid to solid ratio (L/S) of 2, 4, 10, 15, 20, 30 and 40 1/kg over a 24-hour period as the EN 12457 standard (EN 12457 1-2, 2002) provides. Leaching tests used seawater and $\mathrm{CO}_{2}$-acidified seawater at $\mathrm{pH}$ values of 7, 6 and 5 as leaching agents (Payán et al 2012a).

Column leaching tests were carried out according to the CEN/TS 14405 standard (CEN/TS 14405 2004) using the same leaching agents than in equilibrium leaching tests. However, in these experiments, the L/S ratios of $0.1,0.2,0.5,1,2,4,5$, and 10 were employed in experiments that lasted $56 \mathrm{~h}$ (Payán et al. 2012b).

The $\mathrm{pH}$-dependent leaching test with initial acid/base addition was performed following the CEN/TS 14429 standard (CEN/TS 14429 2005) although three modifications were included: the use of seawater as leaching agent, the particle size of the solid $(2 \mathrm{~mm})$ and the $\mathrm{pH}$ range covered (Martín-Torre et al. $2015 \mathrm{a}$ ). The whole $\mathrm{pH}$ range $(0-14)$ is studied for simulating different acidification and alkalinisation situations, including seawater conditions, ocean acidification, leakages from $\mathrm{CO}_{2}$ storage sites and potential chemical spills. For this test, samples of $\mathrm{L} / \mathrm{S}=10 \mathrm{l} / \mathrm{kg}$ were used in experiments that lasted $48 \mathrm{~h}$. The acidified state 
was achieved by adding predetermined amounts of acid $\left(\mathrm{HNO}_{3}\right)$ in three stages (at 0,30 and $120 \mathrm{~min}$ ), as explained in the standard. The quantity of added acid varied from 0 to $8 \mathrm{eq} / \mathrm{kg}$ whereas the quantity of added base was from 0 to $3.5 \mathrm{eq} / \mathrm{kg}$; thus, the obtainment of the most extreme $\mathrm{pH}$ values was assured (Martín-Torre et al. 2015 a; 2014).

The pH-dependent leaching test with continuous pH-control standard (CEN/TS 14997, 2006) was conducted using seawater as leaching liquid. The seawater and the sediment were placed at $\mathrm{L} / \mathrm{S}=10 \mathrm{l} / \mathrm{kg}$. For reaching the pH objective $(4,5,5.5,6,6.5$ or 7$)$ and keep it constant through the 96 hours of the assay, nitric acid $\left(\mathrm{HNO}_{3}\right)$ was added by a pump connected to a $\mathrm{pH}$ control equipment when $\mathrm{pH}$ was higher than the established set point.

To detail the performed leaching tests and clarify the modifications compared with standardized leaching tests, more information about experimental procedure is presented in Supplementary Information.

$\mathrm{pH}$ of the final eluates from the different assays was measured using a Crison pHmeter GLP 22, with a suitable electrode for samples with suspended solids; the equipment was calibrated against standard solutions with an accurate to $0.01 \mathrm{pH}$ units. Final eluates samples were filtered through a $0.45 \mu \mathrm{m}$ pore size nitrocellulose filtration membrane and divide in two subsamples: one for the measurement of Dissolved Organic Carbon (DOC) and the other one acidified for analysing the concentrations of As, $\mathrm{Cd}, \mathrm{Cr}, \mathrm{Cu}, \mathrm{Ni}$, $\mathrm{Pb}$ and $\mathrm{Zn}$. DOC analyses were performed by Analytical Services Unit of Sosprocan (University of Cantabria) following UNE-EN 1484 with a total organic carbon Schimadzu TOC-V Analyzer, applying the difference method Total Organic Carbon=Total Carbon-Total Inorganic Carbon (TOC=TC-TIC). Calibration was done using five dissolutions from 5 to $200 \mathrm{mg} / \mathrm{l}$ DOC. Accuracy was measured analysing patron dissolutions (50 and $100 \mathrm{mg} / \mathrm{l}$ TOC) each 15 samples and a blank solution each 5 samples. Element concentrations were determined by Metal Analysis Center of Scientific and Technological Center (University of Barcelona) using an Agilent 7500CE inductively coupled plasma-mass spectrometry (ICPMS) equipment in helium-collision mode and by a Perkin Elmer Optima 3200 RL inductively coupled plasma-optical emission spectrometry (ICP-OES) equipment. Metal standards for ICP-MS analysis of 1000 mg/L were purchased from Merck (Darmstadt, Germany).The Certified Reference Material NASS-5 (Seawater Reference Material for Trace Metals) from NRCC (Ontario, Canada) was analyzed for quality control. Samples were diluted (1:20) with $\mathrm{HNO}_{3} 1 \%$ prior to analysis and $\mathrm{Rh}$ was added as internal 
standard to correct for eventual drift of signal during analysis. The metal concentrations were calculated using external calibration with internal standard correction. The NASS-5 CRM was spiked with the elements at two different concentration levels 1 and $10 \mathrm{ppb}$. The CRM and the two spiked levels of concentration were measured every 6 samples as quality control. The detection limits for the elements under study (As, $\mathrm{Cd}, \mathrm{Cr}, \mathrm{Cu}, \mathrm{Ni}, \mathrm{Pb}$ and $\mathrm{Zn}$ ) were 2, 0.4, 4, 2, 2, 0.4 and $10 \mu \mathrm{g} / \mathrm{l}$, respectively. All leaching tests were performed in duplicate and the results shown in next tables are the medium value of both data. Prior to the experiments, all sampling and laboratory material was pre-cleaned, acid washed $\left(10 \% \mathrm{HNO}_{3}\right)$ and rinsed with Milli-Q water (Direct-Q 5 UV, Merck Millipore).

The data used in this work includes 60 samples from leaching tests with $\mathrm{CO}_{2}$ acidification (28 samples from the equilibrium leaching tests and 32 samples from column leaching tests) and 24 samples from $\mathrm{pH}-$ dependent leaching tests with $\mathrm{HNO}_{3}$ acidification (18 samples from tests with initial addition and 6 samples from tests with continuous $\mathrm{pH}$-control). Each set of data has been analyzed separately by the SOM methodology (Figure 1).

The data analysis included quantification of $\mathrm{As}, \mathrm{Cd}, \mathrm{Cr}, \mathrm{Cu}, \mathrm{Ni}, \mathrm{Pb}, \mathrm{Zn}$ as well as the mobilization and concentration of Dissolved Organic Carbon (DOC). These variables were chosen to evaluate the contaminants released into the seawater because of leaked $\mathrm{CO}_{2}$ coming into contact with contaminated sediments. The complete dataset with the values of the eight variables obtained in the different leaching tests is provided in Table 2 and Table 3.

\section{Self-Organizing Maps (SOMs)}

The SOM tool applied to the environmental classification of sediments has been previously used by the authors; in these works (Alvarez-Guerra, 2008, 2010), the SOM it is show as an effective tool for the integration of multiple physical, chemical and ecotoxicological variables in order to classify different sites under study according to their similar sediment quality. Details about the methodology background and use of the SOM are described in these previous articles. Briefly, a SOM is a statistical tool based on a neural network with the SOM considered a map that consists of units (neurons) organized on a regular grid, usually a 2-dimensional hexagonal grid. Each neuron is represented by a weighted vector (prototype vector or codebook vector) whose dimension is equal to the dimension of the input space. The SOM Toolbox for 
Matlab (version 2) was used to carry out the analysis, which was based on unsupervised learning and was trained using the Kohonen algorithm (Vesanto et al. 1999; Kohonen 1998).

This methodology uses two distinct phases: the initialization, where the simple vectors of the input dataset are presented to the SOM as a whole, and the training steps that involves iterative calculating and comparing Euclidean distances between each vector and all the weigh vectors of the SOM (Vesanto et al., 1999). The neuron with the input vector at minimum distance to the weigh vector was chosen as the BestMatching Unit (BMU) (Álvarez-Guerra et al. 2008). In each training step, the weight vectors were updated in such a way that the new weight vectors are weighted averages of the input data vectors. During this iterative training, the SOM behaves like a flexible net that folds onto the 'cloud' formed by the input data with BMUs of similar data samples being closely co-located on the final map grid (Vesanto et al. 1999; Álvarez-Guerra et al. 2008).

The SOM analysis displays the obtained results in a map. This map shows which unit is the BMU inside each element in the input data (in this work, the different leaching tests samples). As the iterations described above proceed, the samples that exhibit similar values of the evaluated variables are expected to be assigned to the same neuron, while the samples with differing values are expected to be distant from each other. The 'Component planes' are the tool to interpret the SOM results, emphasizing identical values of the weight vectors for each component (eight in this work) in each neuron. Simple inspection of a component plane provides an idea of the spread of values of that variable and comparison of component planes allows correlations between variables to be observed (Álvarez-Guerra et al. 2008).

Normalization of variables is of vital importance because of the SOM algorithm uses Euclidean metrics to measure distances between vectors (Vesanto et al. 1999). The Normalization removes the influence of the scalar of measurement of the variables, avoiding variables with high values dominating the maps on account of their greater influence on the Euclidean distances (Álvarez-Guerra et al. 2010). Three normalization methods available in the SOM Toolbox were considered: standardization, which normalizes the variance of each variable to unity and its mean to zero ('var'); normalization, which scales the variable values in the range $0-1$ with a linear transformation ('range'); and normalization using a logarithmic transformation ('log') (Álvarez-Guerra et al. 2008). 
The quantization error (QE) and the topographic error (TE) are two criteria used to evaluate the quality of SOMs obtained, permitting comparison between the suitability of the various normalization methods (Vesanto et al. 1999; Álvarez-Guerra et al. 2008). QE is the average distance between each data vector and its BMU and, thus, measures map resolution (Kohonen 2001; Álvarez-Guerra et al. 2010). TE is used as a measure of topology preservation; it represents the proportion of all data vectors for which the first and the second BMUs are not adjacent (Kiviluto 1996; Álvarez-Guerra et al. 2010).

The map size is important in SOMs in detecting any deviation in the data. If the map is too large, the SOM can be over-fitted, but if the map is too small, some differences cannot be shown (Álvarez-Guerra et al. 2010, 2008; Lee et al. 2006; Leflaive et al. 2005).

The algorithm proposed by Alhoniemi et al. (2002) was applied to decide the size of the SOM. In this algorithm, the optimum map size is estimated to be five times the square root of the number of the input data vectors, and then is further refined according to the ratio of the two largest eigenvalues of the input (Álvarez-Guerra et al. 2010). Therefore, each analysis was trained with different map sizes, and the optimum map size was determined on the basis of the minimum QE and minimum TE. The k-means cluster analysis method (MacQueen et al. 1967), which minimizes the sum of the distances between each data vector and the center of its cluster, was used to group neurons of the trained map into a smaller number of clusters that represent similar behaviors (Vesanto and Alhoniemi, 2000). Detailed information about SOM is included in the Supplementary Information.

\section{RESULTS AND DISCUSSION}

\section{Classification of equilibrium and column leaching tests with $\mathrm{CO}_{2}$-acidification}

The results of QE and TE for the three normalization methods applied and different map sizes are shown in Table 4.

'Range' was the normalization method that obtained the lowest values of QE and TE. A 49-unit map $(7 \times 7)$ was selected as the best compromise between a low QE and an acceptable number of neurons, similar to the size of the 34-unit map proposed by the Alhoniemi et al. (2002) algorithm. Interestingly, in this case TE was zero, so the map preserved the topology of the input data very well (Kohonen 2001). Figure 2 represents the SOM of $7 \times 7$ units obtained. The application of the k-means algorithm to the 
trained map classified the samples into five clusters (Clusters I-V). Figure 3 shows the component planes of the SOM for the eight solubilized constituents from the equilibrium and column leaching tests.

Cluster I grouped all of the column leaching tests $(\mathrm{Ec})$ at the most acidic conditions $(\mathrm{pH} 5)$ for all the values of $\mathrm{L} / \mathrm{S}$ evaluated in this test $(0.1,0.2,0.5,1,2,4,5$ and 10). The main characteristic of the leaching test of this cluster was that these samples showed the highest levels of mobilization of $\mathrm{Cu}, \mathrm{Pb}$ and $\mathrm{Zn}$ (Figure 3).

Cluster II grouped the equilibrium leaching tests (Eq) at $\mathrm{pH} 5$ at low $\mathrm{L} / \mathrm{S}$ ratios $(2,4$ and 10$)$. This cluster was characterized by the highest release of $\mathrm{Cd}$ and $\mathrm{Ni} . \mathrm{Cu}, \mathrm{Cd}, \mathrm{Ni}, \mathrm{Pb}$ and $\mathrm{Zn}$ showed higher releases at $\mathrm{pH}$ 5 and values of the L/S ratio lower than 15 in both equilibrium and column leaching tests. A decreasing amount of metal-release with neutral and slightly alkaline $\mathrm{pH}$ values was observed for these metals. This is thought to be related to the higher adsorption of some pollutants to soil and sediments at higher $\mathrm{pH}$ values (Payán et al. 2012b; Voegelin et al. 2003).

Cluster III included samples from both leaching tests. This cluster contained all of the column leaching test samples at $\mathrm{pH} 6$ and a number of those at $\mathrm{pH} 7(\mathrm{~L} / \mathrm{S}=0.2,05,1,2,4$ and 10) and $\mathrm{pH} 8(\mathrm{~L} / \mathrm{S}=4$ and 10). Furthermore, equilibrium leaching test samples for the highest values of the $\mathrm{L} / \mathrm{S}$ ratio $(30$ and 40$)$ at all $\mathrm{pH}$ values and equilibrium leaching test samples for the $\mathrm{L} / \mathrm{S}$ ratio of 10 at $\mathrm{pH}$ values of 6 and 7 were placed in this cluster. Therefore, this cluster collected samples at $\mathrm{pH}$ values of 6 and 7 at $\mathrm{L} / \mathrm{S}$ ratios lower than 10 in the column leaching test and samples at the same $\mathrm{pH}$ at $\mathrm{L} / \mathrm{S}$ ratios higher than 10 in the equilibrium leaching test. This cluster was characterized by minimum values of solubilization for all variables evaluated (Figure 3). This could be because this cluster grouped the highest values of the L/S ratio for both leaching tests and when the exchangeable fraction has been depleted, the dilution of leachates is more accentuated as the L/S ratio increases (Payán et al. 2012a; Ndiba and Axe 2010).

Cluster IV showed a similar situation to Cluster III. Here, column leaching test samples at elevated pH (7 and 8) for low values of the $\mathrm{L} / \mathrm{S}$ ratio $(0.1$ at $\mathrm{pH} 7$ and $0.1,0.2,0.5,1$ and 2 at $\mathrm{pH} 8)$ were found. Also located here were equilibrium leaching test samples at circum-neutral to slightly alkaline $\mathrm{pH}(6,7$ and 8$)$ at $\mathrm{L} / \mathrm{S}$ ratios of 2 and 4 , and $\mathrm{L} / \mathrm{S}=10$ for $\mathrm{pH} 8$. The cluster comprised the samples at $\mathrm{pH}$ values between 7 and 8 from the lowest values of the L/S ( 0.1 to 2$)$ in the column leaching test, and samples at $\mathrm{pH} 8$ from values of the L/S of 2 and above in the equilibrium leaching test. The results additionally show that these samples produced elevated concentration of DOC and As. DOC was mainly leached in alkaline ( $\mathrm{pH} 8$ ) conditions 
with low values of the L/S ratio $(0.1-1 / 1 / \mathrm{kg}$ in column tests and $2-41 / \mathrm{kg}$ in equilibrium tests), that approached typical pore water solutions. Solubilization of organic matter was responsible for the decreased releases at high values of the L/S that can be further attributed to the decreased availability of DOC after its initial dissolution (Payán et al. 2012b). Arsenic displayed a similar trend in leaching behavior, which was associated with organic matter with the highest releases at higher $\mathrm{pH}$ values ( 7 and 8 ) and lower values of the L/S (2-4). We highlight that As could also be mobilized after dissolution of oxides (Achard et al. 2012).

Cluster $\mathrm{V}$ contained samples of all $\mathrm{pH}$ values with $\mathrm{L} / \mathrm{S}$ ratios of 15 and 20 in the equilibrium leaching test and samples that exhibited the maximum levels of $\mathrm{Cr}$ mobilization. The amphoteric character of $\mathrm{Cr}$ leads to it leaching in both acidic and alkaline conditions.

The maximum release of $\mathrm{Ni}$ and $\mathrm{Cr}$ were observed in equilibrium leaching tests whereas the $\mathrm{Cu}, \mathrm{Zn}$ and $\mathrm{Pb}$ were found to mobilize more readily during column leaching tests. Cd, As and DOC presented similar release patterns in both of the included leaching tests.

Figure 4 shows a qualitative map where the three variables analyzed in this paper (leaching test, value of $\mathrm{pH}$ and L/S) are summarized for each cluster. Clusters I and III simulated advective flow of acidified seawater through the sediment column and the results highlight the release of $\mathrm{Cu}, \mathrm{Pb}$ and $\mathrm{Zn}$ in acidic conditions at low L/S values. Clusters II, IV and V simulate $\mathrm{CO}_{2}$ bubbling over contaminated sediment and show high releases of $\mathrm{Cd}, \mathrm{Ni}, \mathrm{Cr}$ and $\mathrm{As}$ at low-to-medium values of $\mathrm{L} / \mathrm{S}$ across the entire $\mathrm{pH}$ range.

\section{Classification of pH-dependent leaching tests with $\mathrm{HNO}_{3}$-acidification}

The results of QE and TE for the three normalization methods applied and the different map sizes are summarized in Table 5 .

"Range" was again the normalization method that obtained the lowest values of QE and TE. A 24-unit map $(6 \times 4)$ was selected as the best compromise between a low QE and a number of neurons that matched the 24-unit map size proposed by the Alhoniemi et al. (2002) algorithm. TE was again zero, indicating that the map preserved the topology of the input data very well (Kohonen 2001). Figure 5 shows the SOM of $6 \times 4$ units that was obtained. 
The application of the k-means algorithm to cluster the trained map classified the samples into five clusters (Clusters I-V) (Figure 5). Figure 6 shows the component planes of the SOM for the eight mobilized constituents from the $\mathrm{pH}$-dependent leaching tests.

Cluster I grouped $\mathrm{pH}-$ dependent leaching test samples with $\mathrm{pH}$ in the range 4-11. Additionally, aside from the sample at $\mathrm{pH} 4$, all of the $\mathrm{pH}$-dependent tests with continuous $\mathrm{pH}$-control (Edc) samples were located in this cluster. The main characteristic of the results of leaching tests in this cluster was that these samples showed intermediate values for solubilization of $\mathrm{DOC}, \mathrm{Cu}$ and $\mathrm{As}$ and minimum solubilization of the rest of the metals. These results are explained by the neutral and alkaline conditions grouped in this cluster (Figure 6).

Cluster II collected the samples for $\mathrm{pH}$-dependent tests with initial addition (Ed) where alkaline values of $\mathrm{pH}$ were simulated. This cluster was characterized by a high release of DOC and As. DOC is known to be released in alkaline solutions because of the higher negative charges on both organic matter and soil surfaces that cause the particles to repel each other (You et al. 1999). The release trend of As was similar to that of DOC, showing a maximum concentration and a high release of As in alkaline conditions. Again, this is due to the negatively charged surfaces above the point of zero charge; above this point, the sorption of anions is less favorable (Rigol et al. 2009).

Cluster III grouped the $\mathrm{pH}$-dependent test with initial addition (Ed) samples for $\mathrm{pH}$ values between 3.97 and 4.42. Intermediate values of release for all variables evaluated were located in this cluster.

Cluster IV comprises only samples of $\mathrm{pH}$ dependence test with initial addition where $\mathrm{pH}$ was found between 0.6 and 2.49. The main characteristic of the leaching test of this cluster was that these samples showed the highest levels of leached $\mathrm{Cr}$ and $\mathrm{Ni}$ (Figure 6).

The samples which have the highest acid $\mathrm{pH}$ for both tests are grouped in cluster $\mathrm{V}(\mathrm{pH}=4$ for $\mathrm{pH}$ dependence test with continuous $\mathrm{pH}$-control, and $\mathrm{pH}=0.27$ for $\mathrm{pH}$ dependence test with initial addition). The maximum release of $\mathrm{Cd}, \mathrm{Cu}, \mathrm{Pb}$, and $\mathrm{Zn}$ are located in this cluster.

The maximum leaching rates of $\mathrm{Cd}, \mathrm{Cr}, \mathrm{Cu}, \mathrm{Ni}, \mathrm{Pb}$, and $\mathrm{Zn}$ were observed at $\mathrm{pH}$ ranged from 0 to 4 (clusters IV and $\mathrm{V}$ ). The release of $\mathrm{Cr}, \mathrm{Ni}, \mathrm{Pb}$ and $\mathrm{Zn}$ at these conditions is consistent with the observation that in acidic conditions, the solid sediment surfaces are positively charged and metal-sorption is not 
favored. Furthermore, dissolution of organo-metallic complexes is expected in these conditions leading to a higher metal-release than in alkaline conditions. In this work, $\mathrm{Cu}$ release is higher at acidic $\mathrm{pH}$ values due to the low sorption of this metal in these acidic conditions (Güngör and Bekbolet 2010; Impellitteri et al. 2002; Almås et al. 2000).

The maximum release of all variables evaluated (a worst-case scenario) took place in the $\mathrm{pH}$-dependent test with initial addition (where the $\mathrm{pH}$ condition is fixed initially). The release under this testing regime was higher than that expected for a $\mathrm{pH}-$ dependent test with continuous $\mathrm{pH}$-control.

Figure 7 shows the qualitative map for the $\mathrm{pH}$-dependent leaching tests with the $\mathrm{pH}$, the $\mathrm{L} / \mathrm{S}$ ratio and the leaching test for each obtained cluster.

\section{CONCLUSIONS}

This paper used a SOM-based methodology for interpreting and analyzing the information collected from the classification of 60 samples obtained from equilibrium and column leaching laboratory tests using $\mathrm{CO}_{2}$ acidified seawater. The combination of the leaching results with the statistical treatment of SOMs provides conclusions about the mobilization of elements from contaminated seabed sediments because of $\mathrm{CO}_{2}$ leakages and, for example, illustrated that for $\mathrm{Ni}$ and $\mathrm{Cr}$ the mobilization is higher in equilibrium leaching tests at $\mathrm{L} / \mathrm{S}=10$ and $\mathrm{pH} 5$ for $\mathrm{Ni}$, and at the $\mathrm{L} / \mathrm{S}$ ratio of 20 at all values of $\mathrm{pH}$ for $\mathrm{Cr}$.

For $\mathrm{Cu}, \mathrm{Zn}$ and $\mathrm{Pb}$, the highest risk of mobilization was originated in column leaching tests at $\mathrm{pH} 5$ and at $\mathrm{L} / \mathrm{S}$ ratios of 2, 4, 5 and 10. The risk of mobilization of $\mathrm{Cd}, \mathrm{As}$ and $\mathrm{DOC}$ was present in both tests. However, while the maximum DOC mobilization was found in column leaching tests with a pH of seawater $(\mathrm{pH}=8)$ and a low $\mathrm{L} / \mathrm{S}$ ratio, $\mathrm{Cd}$ and As presented a stronger leachability in equilibrium leaching tests. Acidic conditions (pH 5 at the ratio L/S of 10 and $\mathrm{pH}$ values of 6 and 7 at the ratio $\mathrm{L} / \mathrm{S}$ of 2 and 4) were responsible for the highest levels of mobilization of other elements ( $\mathrm{Cd}$ and $\mathrm{As})$.

The analysis of 24 samples obtained from $\mathrm{pH}$-dependent leaching tests using $\mathrm{HNO}_{3}$-acidified seawater at a constant $\mathrm{L} / \mathrm{S}$ value of 10 showed that the maximum mobilization of $\mathrm{DOC}, \mathrm{As}, \mathrm{Cd}, \mathrm{Cr}, \mathrm{Cu}, \mathrm{Ni}, \mathrm{Pb}$ and $\mathrm{Zn}$ variables was produced in samples of $\mathrm{pH}$-dependent leaching tests with initial addition. For all studied 
elements except As, a more acidic sample led to a higher release of elements. Conversely, the release of DOC and As was higher in alkaline conditions.

The results described herein are useful for simulating element-release from contaminated sediment in contact with acidified seawater under different environmental conditions. This scenario could equally apply to marine acidification caused by $\mathrm{CO}_{2}$ leakages from $\mathrm{CCS}$ technologies as well as arising from other accidental spills of acid.

Finally, the SOM-method has demonstrated its advantage as a powerful visualization tool that enables analysis of the impact on a number of variables.

\section{ACKNOWLEDGMENTS}

This work was supported by the Spanish Ministry of Economy and Competitiveness under Project CTM 2011-28437-C02-01, ERDF included. MCMT was funded by the Spanish Ministry of Economy and Competitiveness by F.P.I. fellowship Nº BES-2012-053816.

\section{COMPLIANCE WITH ETHICAL STANDARDS}

The authors declare that they have no conflict of interest.

\section{REFERENCES}

1. Achard, R., Benard, A. \& Lucas, Y. (2012). Environmental behavior of inorganic pollutants present in raw and desalinated French marine sediments, WASCON Conference Proceedings, Gothenburg, Sweden, May 30-June 1, 2012; Arm, M, Vandescasteele, C, Heynen, J., Suer, P. Lind, B. Eds. Iscowa and SGI: 2012.

2. Akai, M., Nomura, N., Waku, H. \& Inoue, M. (1997). Life-Cycle Analysis of a fossil-fuel power plant with $\mathrm{CO}_{2}$ recovery and a sequestration system. Energy, 22, 249-255.

3. Alhoniemi, E., Himber, J., Parhankangas, J. \& Vesanto, J. (2002). SOM toolbox: Create and initialize a topology struct, SOM $\quad$ Toolbox online documentation. http://www.cis.hut.fi/projects/somtoolbox/package/docs2/som topol_struct.html (accessed Oct, 9, 2014). 
4. Almas, A., McBride, M.B. \& Singh, B.R. (2000). Solubility and liability of cadmium and zinc in two soils treated with organic matter. Soil Science, 165, 250-259.

5. Álvarez-Guerra, M., González-Piñuela, C., Andrés, A., Galán, B. \& Viguri, J.R. (2008). Assessment of Self-Organizing Map artificial neural networks for the classification of sediment quality. Environment International, 34, 782-790.

6. Álvarez-Guerra, E., Molina, A., Viguri, J.R. \& Álvarez-Guerra, M. (2010). A SOM-based methodology for classifying air quality monitoring stations. Environmental Progress and Sustainable Energy, 30, 424-438.

7. Ardelan, M. V., Steinnes, E., Lierhagen, S. \& Linde, S.O. (2009). Effects of experimental $\mathrm{CO}_{2}$ leakage on solubility and transport of seven trace metals in seawater and sediment. Science of the Total Environment, 407, 6255-6266.

8. Ardelan, M. V. \& Steinnes, E. (2010). Changes in mobility and solubility of the redox sensitive metals $\mathrm{Fe}, \mathrm{Mn}$ and $\mathrm{Co}$ at the seawater-sediment interface following $\mathrm{CO}_{2}$ seepage. Biogeosciences, 7, 569-583.

9. Ardelan, M.V., Sundeng, K., Slinde, G.A., Gjosund, N.S., Nordtug, T., Olsen, A.J., Steinnes, E. \& Torp, T.A. (2012). Impacts of possible $\mathrm{CO}_{2}$ seepage from sub-seabed storage on trace elements mobility and bacterial distribution at sediment-water interface. Energy Procedia, 23, 449-461.

10. Arias, R., Barona, A., Ibarra-Berastegi, G., Aranquiz, I. \& Elías, A. (2008). Assessment of metal contamination in dredged sediments using fractionation and Self-Organizing Maps. Journal of Hazardous Materials, 151, 78-85.

11. Birkholzer, J. \& Berkeley, L. (2008). Research project on $\mathrm{CO}_{2}$ geological storage and groundwater resources. Water quality effects caused by $\mathrm{CO}_{2}$ intrusion into shallow groundwater. University of California. October 2008.

12. BMU (2008). Federal Ministry for the Environment, Nature Conservation and Nuclear Safety. Ecological, Economic and Structural Comparison of Renewable Energy Technologies (RE) with Carbon Capture and Storage (CCS)-An Integrated Approach.

13. Carey, J.W., Svec, R., Grigg, R., Lichtner, P.C., Zhang, J. \& Crow, W. (2009). Wellbore integrity and $\mathrm{CO}_{2}$-brine flow along the casing-cement microannulus. Energy Procedia, 1, 3609-3615. 
14. CEN/TS 14405 (2004). Characterization of Waste-Leaching Behavior Tests of Upflow Percolation Test (Under Specified Conditions).

15. CEN/TS 14429 (2005). Characterization of waste-Leaching behavior tests-Influence of $\mathrm{pH}$ on leaching with initial acid/base addition.

16. CEN/TS 14997 (2006). Characterization of waste-Leaching behavior tests-Influence of $\mathrm{pH}$ on leaching with continuous $\mathrm{pH}$-control.

17. Cesar A., Choueri, R.B., Riba, I., Morales-Caselles, C., Pereira, C.D., Santos, A.R., Abessa, D.M. \& DelValls, T.A. (2007). Comparative sediment quality assessment in different littoral ecosystems from Spain (Gulf of Cadiz) and Brazil (Santos and São Vicente estuarine system). Environment International, $33,429-35$.

18. Chadwick, R.A., Zweigel, P., Gregersen, U., Kirby, G.A., Holloway, S. \& Johannessen, P.N. (2004). Geological reservoir characterization of a $\mathrm{CO}_{2}$ storage site: The Utsira Sand, Sleipner, northern North Sea. Energy, 29, 1371-1381.

19. Choueri, R.B., Cesar, A., Torres, R.J., Abessa, D.M.S., Morais, R.D., Pereira, C.D.S., Nascimento, M.R.L., Mozeto, A.A., Riba, I. \& DelValls, T.A. (2009). Integrated sediment quality assessment in Paranaguá Estuarine System, southern Brazil. Ecotoxicology and Environmental Safety, 72, 1824-1831

20. Corsten, M., Ramirez, A., Shen, L., Koornneef, J. \& Faaij, A. (2013). Environmental impact assessment of CCS chains-Lessons learned and limitations from LCA literature. International Journal of Greenhouse Gas Control, 13, 13 59-71.

21. De Orte, M.R., Sarmiento, A.M., Basallote, M.D., Rodríguez-Romero, A., Riba, I. \& DelValls, A. (2014). Effects on the mobility of metals from acidification caused by possible $\mathrm{CO}_{2}$ leakage from subseabed geological formations. Science of the Total Environment, 470-471, 356-363.

22. DIN EN 1484 (1997). Water analysis. Guidelines for the determination of total organic carbon (TOC) and dissolved organic carbon (DOC).

23. DOL (2008). Directive 2008/56/EC of the European Parliament and of the Council of 17 June 2008 establishing a framework for community action in the field of marine environmental policy (Marine Strategy Framework Directive). Official Journal of the European Union 2562008 L, 164, 19-40. 
24. DOL (2009). Directive 2009/31/EC of the European Parliament and of the Council of 23 April 2009 on the geological storage of carbon dioxide. Official Journal of the European Union 562009 L, 140, 114135.

25. Ellis, B., Peters, C., Fitts, G., Bromhal, G., McIntyre, D., Warzinski, R. \& Rosenbaum, E. (2011). Deterioration of a fractured carbonate caprock exposed to $\mathrm{CO}_{2}$-acidified brine flow. Greenhouse Gases: Science and Technology, 1, 248-260.

26. EN 12457 1-2 (2002). Characterization of Waste-Leaching-Compliance Test for Leaching of Granular Waste Materials and Sludges.

27. Güngör, E. \& Bekbölet, M. (2010). Zinc release by humic and fulvic acid as influenced by $\mathrm{pH}$, complexation and DOC sorption. Geoderma, 159, 131-138.

28. Hertwich, E.G., Aaberg, M., Singh, B. \& Stromman, A.H. (2008). Life-cycle assessment of carbon dioxide capture for enhanced oil recovery. Chinese Journal of Chemical Engineering, 16, 343-353.

29. Hill, T.A., Fackrell, J.E., Dubal, M.R. \& Stiff, S.M. (2011) Understanding the consequences of $\mathrm{CO}_{2}$ leakage downstream of the capture plant. Energy Procedia, 4, 2230-2237.

30. Hou, Z., Rockhold, M.L. \& Murray, C.J. (2012) Evaluating the impact of caprock and reservoir properties on potential risk of $\mathrm{CO}_{2}$ leakage after injection. Environmental Earth Sciences, 66, 2403-2415.

31. Hussain, D., Dzombak, D.A., Jaramillo, P. \& Lowry, G.V. (2013). Comparative lifecycle inventory (LCI) of greenhouse gas (GHG) emissions of enhanced oil recovery (EOR) methods using different $\mathrm{CO}_{2}$ sources. International Journal of Greenhouse Gas Control, 16,129-144.

32. Impellitteri, C.A., Lu, Y., Saxe, J.K., Allen, H.E. \& Peijnenburg, W.J.G.M. (2002). Correlation of the partitioning of dissolved organic matter fractions with the desorption of $\mathrm{Cd}, \mathrm{Cu}, \mathrm{Ni}, \mathrm{Pb}$ and $\mathrm{Zn}$ from 18 Dutch soils. Environment International, 28, 401-410.

33. IPCC (2014). Climate Change 2014: Mitigation of Climate Change. Contribution of Working Group III to the Fifth Assessment Report of the Intergovernmental Panel on Climate Change. Edenhofer, O., Pichs-Madruga,R., Sokona, Y., Farahani, E., Kadner, S., Seyboth, K., Adler, A., Baum, I., Brunner, S., Eickemeier, P., Kriemann, B., Savolainen, J., Schlömer, S., Von Stechow, C., Zwickel, T. and Minx, J.C. (eds.). Cambridge University Press, Cambridge, United Kingdom and New York. 
34. Iribarren, D., Petrakopoulou, F. \& Dufour, J. (2013). Environmental and thermodynamic evaluation of $\mathrm{CO}_{2}$ capture, transport and storage with and without enhanced resource recovery. Energy, 50, 477-485.

35. Keating, E.H. Hakala, J.A., Viswanathan, H., Capo, R., Stewart, B., Gardiner, J., Guthrie, G., William Carey, J. \& Fessenden, J. (2011). The challenge of predicting groundwater quality impacts in a $\mathrm{CO}_{2}$ leakage scenario: results from field, laboratory and modelling studies at a natural analog site in New Mexico, U.S.A. Energy Procedia, 4, 3239-3245.

36. Khoo, H.H. \& Tan, R.B.H. (2006). Life cycle investigation of $\mathrm{CO}_{2}$ recovery and sequestration. Environmental and Science Technology, 40, 4016-4024.

37. Khosrovyan, A., Rodríguez-Romero, A., Antequera Ramos, M., DelValls, T.A. \& Riba, I. (2015) Comparative analysis of two weight-of-evidence methodologies for integrated sediment quality assessment. Chemosphere, 120, 138-144.

38. Kiviluoto, K. (1996). Topology preservation in Self-Organizing maps. Proceedings of the IEEE International Conference on Neural Networks. Washington, DC, USA, June 3-6.

39. Kohonen, T. (1998). The self-organizing map. Neurocomputing, 21, 1-6.

40. Kohonen, T. (2001). Self-organizing maps ( $3^{\text {rd }}$ Edition). Berlin, Germany: Springer.

41. Koornneef, J. Ramírez, A., Turkenburg, W. \& Faaij, A. (2012). The environmental impact and risk assessment of $\mathrm{CO}_{2}$ capture, transport and storage- An evaluation of the knowledge base. Progress in Energy and Combustion Science, 38, 62-86.

42. Korre, A. Shi, J.Q., Imrie, C. \& Durucan, S. (2009). Modelling the uncertainty and risks associated with the design and life cycle of $\mathrm{CO}_{2}$ storage in coalbed reservoirs. Energy Procedia, 1, 2525-2532.

43. Lee, B.H. \& Scholz, M. (2006). A comparative study: prediction of constructed treatment wetland performance with k-nearest neighbors and neural networks. Water, Air and Soil Pollution, 174, 279-301.

44. Leflaive, J., Céréghino, R., Danger, M., Lacroix, G. \& Ten-Hage, L. (2005). Assessment of selforganizing maps to analyze sole-carbon source utilization profiles. Journal of Microbiological Methods, 62, 89-102. 
45. MacQueen, J.B. (1967). Some methods for classification and analysis of multivariate observations. Proceedings of 5th Berkeley Symposium on Mathematical Statistics and Probability, Berkeley, California, June 21-July 18, 1965 and December 27, 1965-January 7, 1966; Le Cam, L., Neyman, J. Eds. California.

46. Martín-Torre, M.C., Payán, M.C., Galán, B., Coz, A. \& Viguri, J.R. (2014). The use of leaching tests to assess metal release from contaminated marine sediment under $\mathrm{CO}_{2}$ leakages from $\mathrm{CCS}$. Energy Procedia 51, 40-47.

47. Martín-Torre, M.C., Payán, M.C., Verbinnen, B., Coz, A., Ruiz, G., Vandecasteele, C., \& Viguri, J.R. (2015a). Metal release from contaminated estuarine sediment under $\mathrm{pH}$ changes in the marine environment. Archives of Environmental Contamination and Toxicology 68(3), 577-587.

48. Martín-Torre, M.C., Ruiz, G. \& Viguri, J.R. (2015b). Generalised mathematical model to estimate Zn, $\mathrm{Pb}, \mathrm{Cd}, \mathrm{Ni}, \mathrm{Cu}, \mathrm{Cr}$ and $\mathrm{As}$ release from contaminated estuarine sediment using $\mathrm{pH}$-static leaching tests. Chemical Engineering Science 138, 780-790.

49. Mazzoldi, A., Hill, T. \& Colls, J.J. (2011). Assessing the risk for $\mathrm{CO}_{2}$ transportation within CCS projects, CFD modelling. International Journal of Greenhouse Gas Control, 5, 816-825.

50. Meyer, V., Houdu, E., Poupard, O. \& Le Gouevec, J. (2009). Quantitative risk evaluation related to long term $\mathrm{CO}_{2}$ gas leakage along wells. Energy Procedia, 1, 3595-3602.

51. Morales-Caselles C., Kalman, J., Riba, I. \& DelValls, T.A. (2007). Comparing sediment quality in Spanish littoral areas affected by acute (Prestige, 2002) and chronic (Bay of Algeciras) oil spills. Environmental Pollution, 146, 233-40.

52. Moukhchan, F., March, J.G. \& Cerdá, V. (2013). Distribution of trace metals in marine sediments of the Bay of Palma de Mallorca (Mallorca Island, Spain). Environmental Monitoring and Assessment, 185, 695-706.

53. Nadal, M. (2005). Human health risk assessment of exposure to environmental pollutants in the chemical / petrochemical industrial area of Tarragona (Catalonia, Spain). European PhD Thesis. Rovira i Virgili University. 
54. Nadal, M., Kumar, V., Schuhmacher, M. \& Domingo, J.L. (2006). Definition and GIS-based characterization of an integral risk index applied to a chemical/petrochemical area. Chemosphere 64, 15261535.

55. Nagashima, S., Miyagawa, T., Matsumoto, M., Sazuki, S., Komaki, H., Takagi, M. \& Murai, S. (2011). Life cycle assessment performed on a CCS model case in Japan and evaluation of improvement facilitated by heat integration. Energy Procedia, 4, 2457-2464.

56. Ndiba, P.K. \& Axe, L. (2010). Risk assessment of metal leaching into groundwater from phosphate and thermal treated sediments. Journal of Environmental Engineering-Asce, 136, 427-434.

57. Nie, Z., Korre, A. \& Durucan, S. (2011). Life cycle modelling and comparative assessment of the environmental impacts of oxy-fuel and post-combustion $\mathrm{CO}_{2}$ capture, transport and injection processes. Energy Procedia, 4, 2510-2517.

58. OSPAR Convention (2007). Guidelines for Risk Assessment and Management of Storage of Carbon Dioxide Streams in Sub-Seabed Geological Formations. OSPAR Convention for the Protection of the Marine Environment of the North- East Atlantic.

59. Payán, M.C., Verbinnen, B., Galán, B., Coz, A., Vandecasteele, C. \& Viguri, J.R. (2012a). Potential influence of $\mathrm{CO}_{2}$ release from a carbon capture storage site on release of trace metals from marine sediment. Environmental Pollution, 162, 29-39.

60. Payán, M.C. Galán, B., Coz, A., Vandecasteele, C. \& Viguri, J.R. (2012b). Evaluation through column leaching tests of metal release from contaminated estuarine sediment subject to $\mathrm{CO}_{2}$ leakages from Carbon Capture and Storage sites. Environmental Pollution, 171, 174-184.

61. Pehnt, M. \& Henkel, J. (2009). Life cycle assessment of carbon dioxide capture and storage from lignite power plants. International Journal of Greenhouse Gas Control, 3, 49-66.

62. RAMF (2006). Assessment and Management Framework for $\mathrm{CO}_{2}$ sequestration in sub-seabed geological formations, in: CS-SSGS. London Convention 1972 and London Protocol, pp. 2-1.

63. Rigol, A., Mateu, J., González-Núñez, R., Rauret, G. \& Vidal, M. (2009). pHstat vs. single extraction tests to evaluate heavy metals and arsenic leachability in environmental samples. Analytica Chimica Acta, 632, 69-79. 
64. Sakamoto, Y., Tanaka, A., Temma, N. \& Komai, T. (2011). Numerical study on flow behaviour of $\mathrm{CO}_{2}$ in an aquifer for risk assessment of carbon capture and storage. Energy Procedia, 4, 4171-4177.

65. Simeonov V., Wolska, L., Kuczynska, A., Gurwin, J. \& Tsakovski, S. (2007).Sediment-quality assessment by intelligent data analysis. TrAC Trends in Analytical Chemistry, 26, 323-31.

66. Singh, B., Stromman, A.H. \& Hertwich, E.G. (2011). Comparative life cycle environmental assessment of CCS technologies. International Journal of Greenhouse Gas Control, 5, 911-921.

67. Singh, B., Stromman, A.H. \& Hertwich, E.G (2012). Environmental damage assessment of carbon capture and storage. Journal of Industrial Ecology, 16, 407-419.

68. Tsakovski, S., Kudlak, B., Simeonov, V., Wolska, L. \& Namiesnik, J. (2009). Ecotoxicity and chemical sediment data classification by the use of self-organising maps. Analytica Chimica Acta, 631, $142-152$.

69. Tsiatsios, C.J. (2005). An assessment of metal release from contaminated estuarine sediment using batch and column leaching tests. M.S. Thesis, University of New Hampshire.

70. Van der Zwaan, B. \& Gerlagh, R. (2009). Effectiveness of CCS with time-dependent $\mathrm{CO}_{2}$ leakage. Energy Procedia, 1, 4977-4984.

71. Varadharajan, C., Tinnacher, R.M., Pugh, J.D., Trautz, R.C., Zheng, L., Spycher, N.F., Birkholzer, J.T., Castillo-Michel, H., Esposito, R.A.\& Nico, P.S. (2013). A laboratory study of the initial effects of dissolved carbon dioxide $\left(\mathrm{CO}_{2}\right)$ on metal release from shallow sediments. International Journal of Greenhouse Gas Control, 19, 183-211.

72. Vesanto, J., Himberg, J., Alhoniemi, E. \& Parhankangas, J. (1999). Self-organizing map in Matlab: the SOM Toolbox. Proceedings of the Matlab DSP Conference, Espoo, Finland, Nov.16-17, 1999; Comsol Oy.

73. Vesanto, J. \& Alhoniemi, E. (2000). Clustering of the self-organizing map. IEEE Transactions on Neural Networks, 11, 586-600.

74. Viebahn, P., Nitsch, J., Fischedick, M., Esken, A., Schüwer, D., Supersberger, N., Zuberbühler, U. \& Edenhofer, O. (2007). Comparison of carbon capture and storage with renewable energy technologies regarding structural, economic, and ecological aspects in Germany. International Journal of Greenhouse Gas Control, 1, 121-133. 
75. Voegelin, A., Barmettler, K. \& Kretzschmar, R. (2003). Heavy metal release from contaminated soils: comparison of column leaching and batch extraction results. Journal of Environmental Quality, 32, 865875.

76. Xiao, Y., Xu, T. \& Pruess, K. (2009). The effects of gas-fluid-rock interactions on $\mathrm{CO}_{2}$ injection and storage: insights from reactive transport modelling. Energy Procedia, 1, 1783-1790.

77. You, S-J., Yin, Y. \& Allen, H.E. (1999). Partitioning of organic matter in soils: effects of $\mathrm{pH}$ and water/soil ratio. Science of the Total Environment, 227, 155-160.

78. Zhou, X., Apple, M.A., Dobeck, L.M., Cunningham, A.B. \& Spangler, L.H. (2013). Observed response of soil $\mathrm{O}_{2}$ concentration to leaked $\mathrm{CO}_{2}$ from an engineered $\mathrm{CO}_{2}$ leakage experiment. International Journal of Greenhouse Gas Control, 16, 116-128. 


\section{Figures}

Assessment by Self-Organizing Maps of element-release from sediments in contact with acidified seawater in laboratory leaching test conditions

I. Muñoz $\left.{ }^{(1)}{ }^{*}\right)$, M.C. Martín-Torre ${ }^{(1)}$, B. Galán ${ }^{(1)}$, J.R. Viguri ${ }^{(1)}$

(1) GER Green Engineering and Resources Group. Department of Chemistry and Process \& Resource Engineering, ETSIIT, University of Cantabria, Spain.

${ }^{(*)}$ Corresponding author: (942)201583, munozi@unican.es

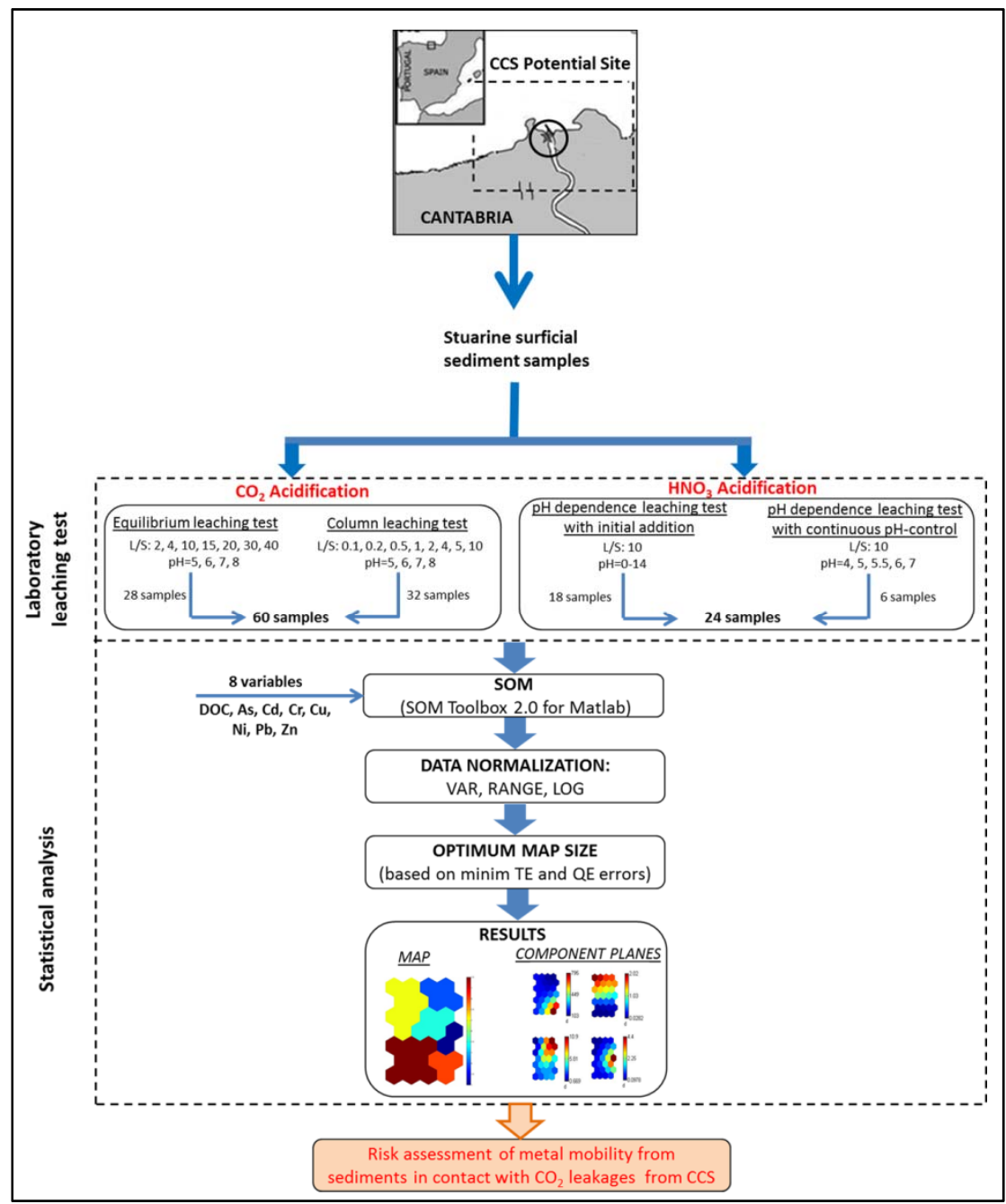

Fig1. Schematic representation of the methodology followed in this study. 


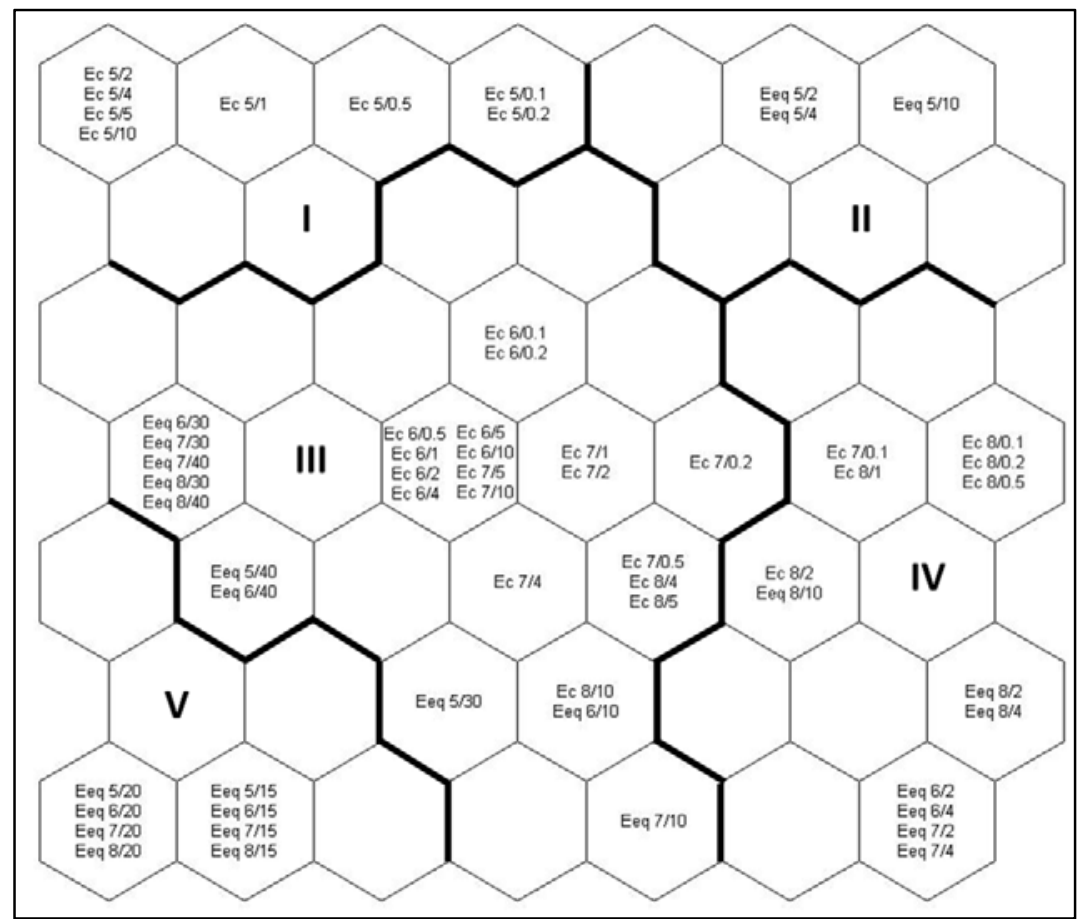

Fig2. Distribution of equilibrium and column leaching tests acidified with $\mathrm{CO}_{2}$ samples. The 5 clusters (IV) have been derived from the $k$-means algorithm applied to the trained SOM. The labels in the hexagons of the map show the BMU corresponding to each leaching test sample. 


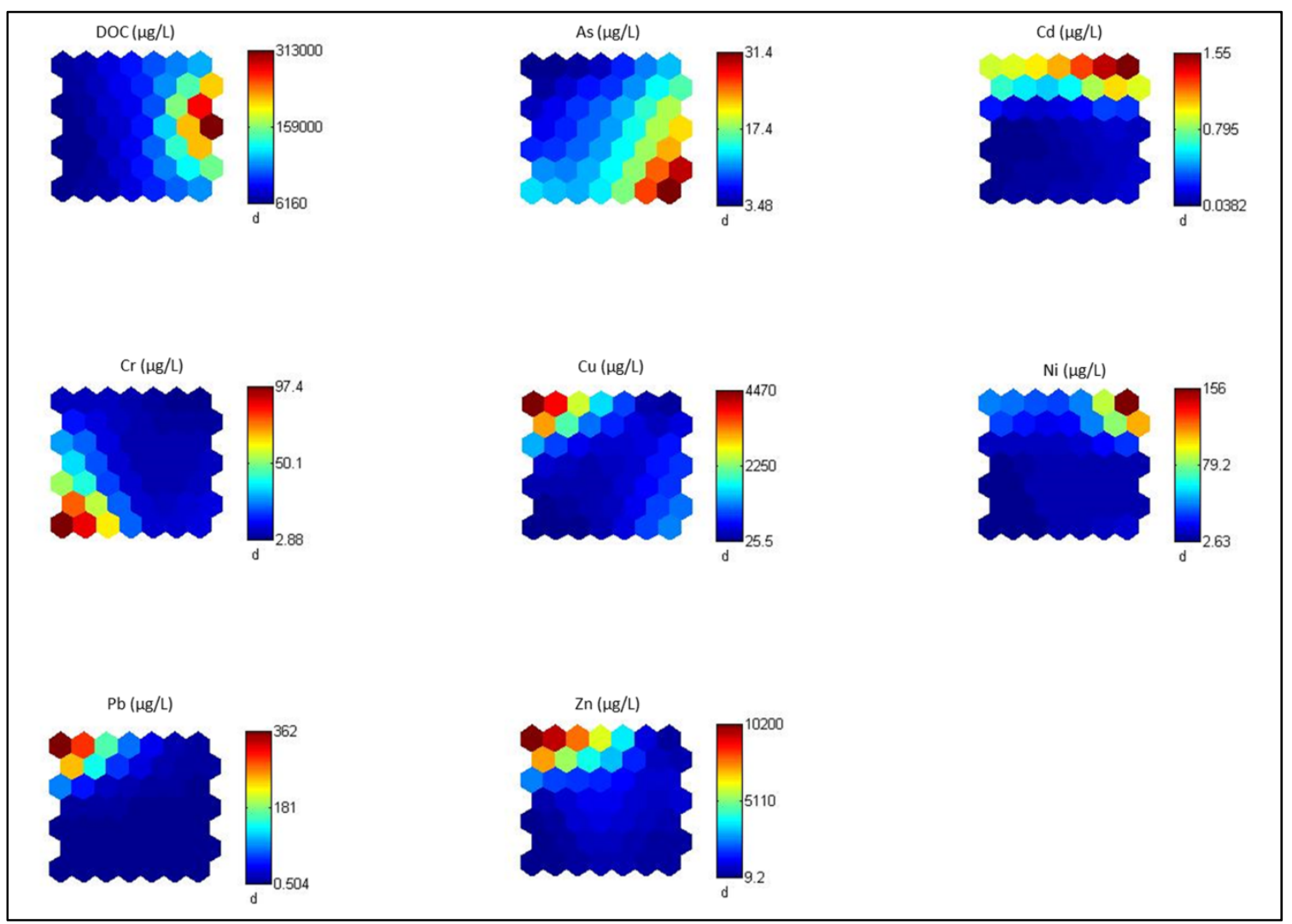

Fig3. Component planes of the SOM for the 8 input variables. Each map corresponding to one variable (component) should be compared to the map representing the distribution of the equilibrium and column leaching tests acidified with $\mathrm{CO}_{2}$ samples presented in Figure 2; hexagons in the same place on different component planes correspond to the same map unit. The colors indicate the value of the component in the weight vector of each unit of the map, according to the color bars on the right. 


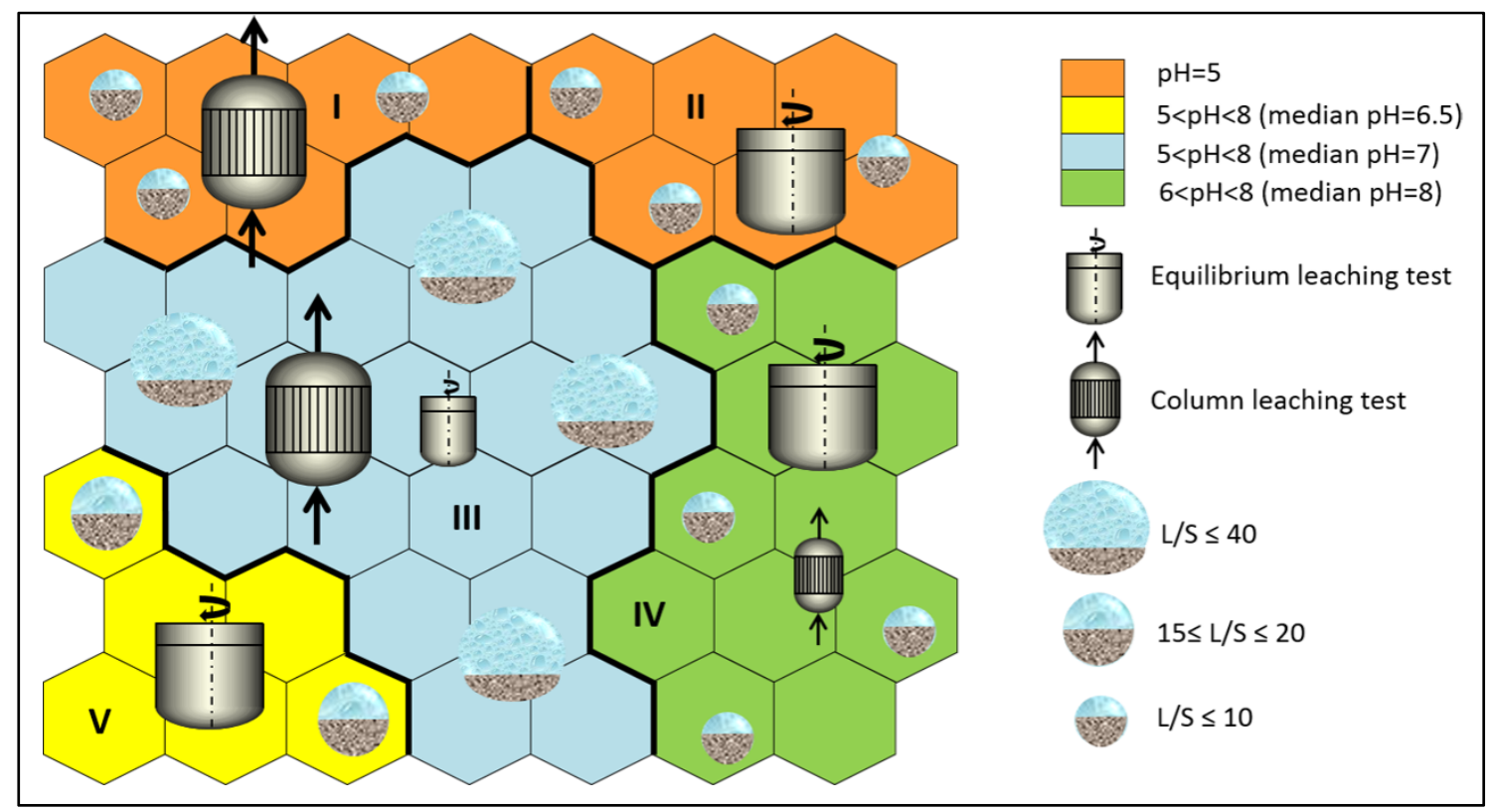

Fig4. Qualitative map for equilibrium and column leaching tests with $\mathrm{CO}_{2}$ acidification. Clusters are characterized by the $\mathrm{pH}$ (color), by the liquid to solid (L/S) ratio with higher sizes of bubbles meaning higher L/S ratios and by the leaching contact, represented by reactors; in clusters with both of the reactors, their relative size is identified with the number of samples of each contact in the cluster.

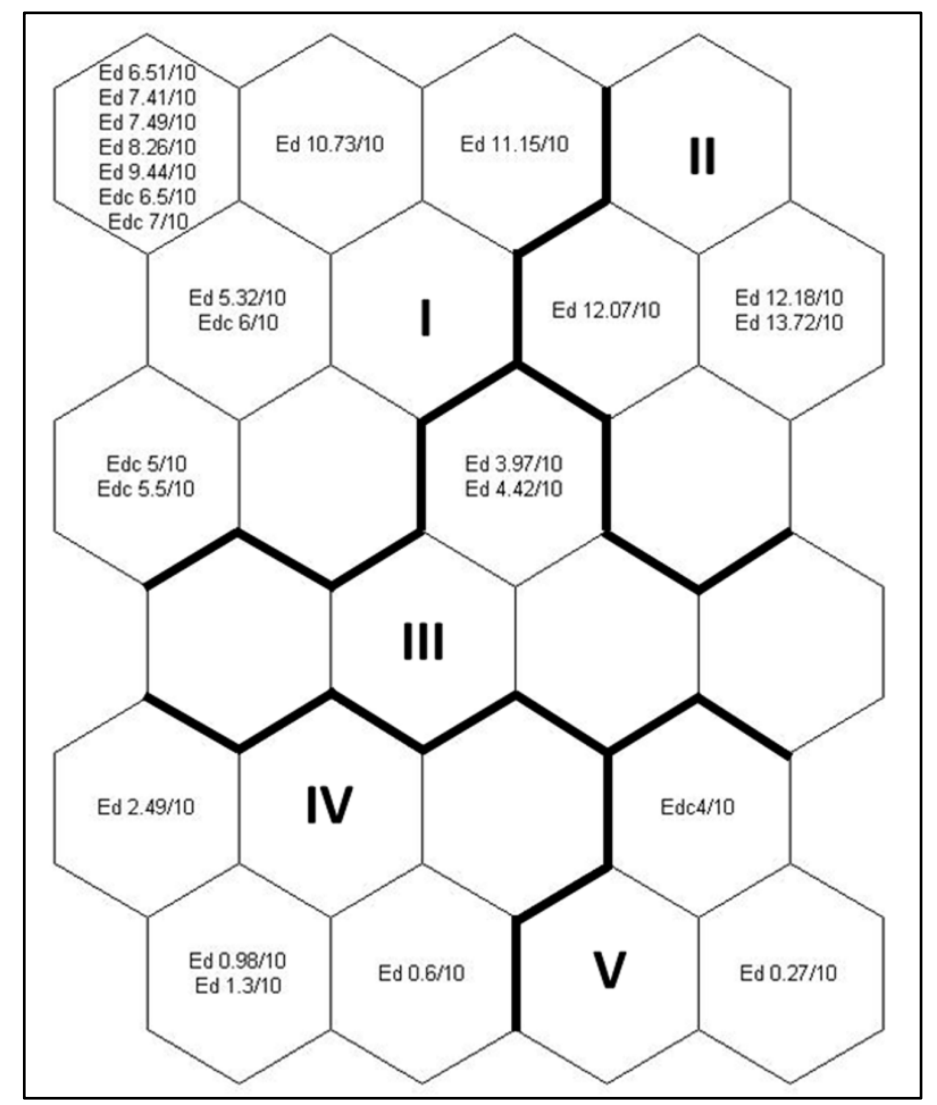

Fig5. Distribution of the $\mathrm{pH}$ dependence leaching test acidified with $\mathrm{HNO}_{3}$ samples. The 5 clusters (I-V) have been derived from the $k$-means algorithm applied to the trained SOM. The labels added to the hexagons of the map indicate the BMU corresponding to each leaching test sample. 


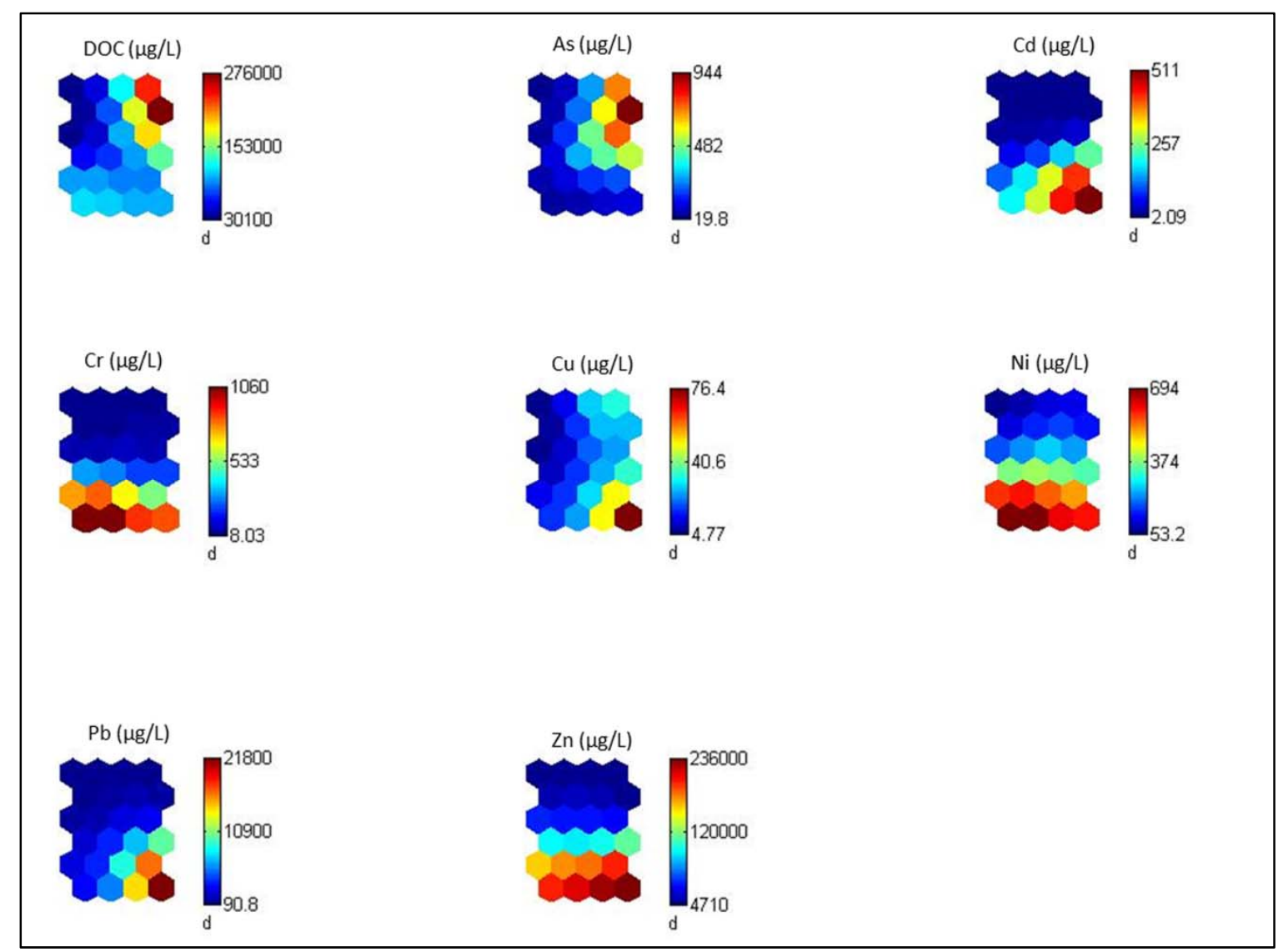

Fig6. Component planes of the SOM for the 8 input variables. Each map corresponding to one variable (component) should be compared to the map representing the distribution of the $\mathrm{pH}$ dependence leaching tests acidified with $\mathrm{HNO}_{3}$ samples presented in Figure 5; hexagons in the same place on different component planes correspond to the same map unit. The colors indicate the value of the component in the weight vector of each unit of the map according to the color bars on the right. 


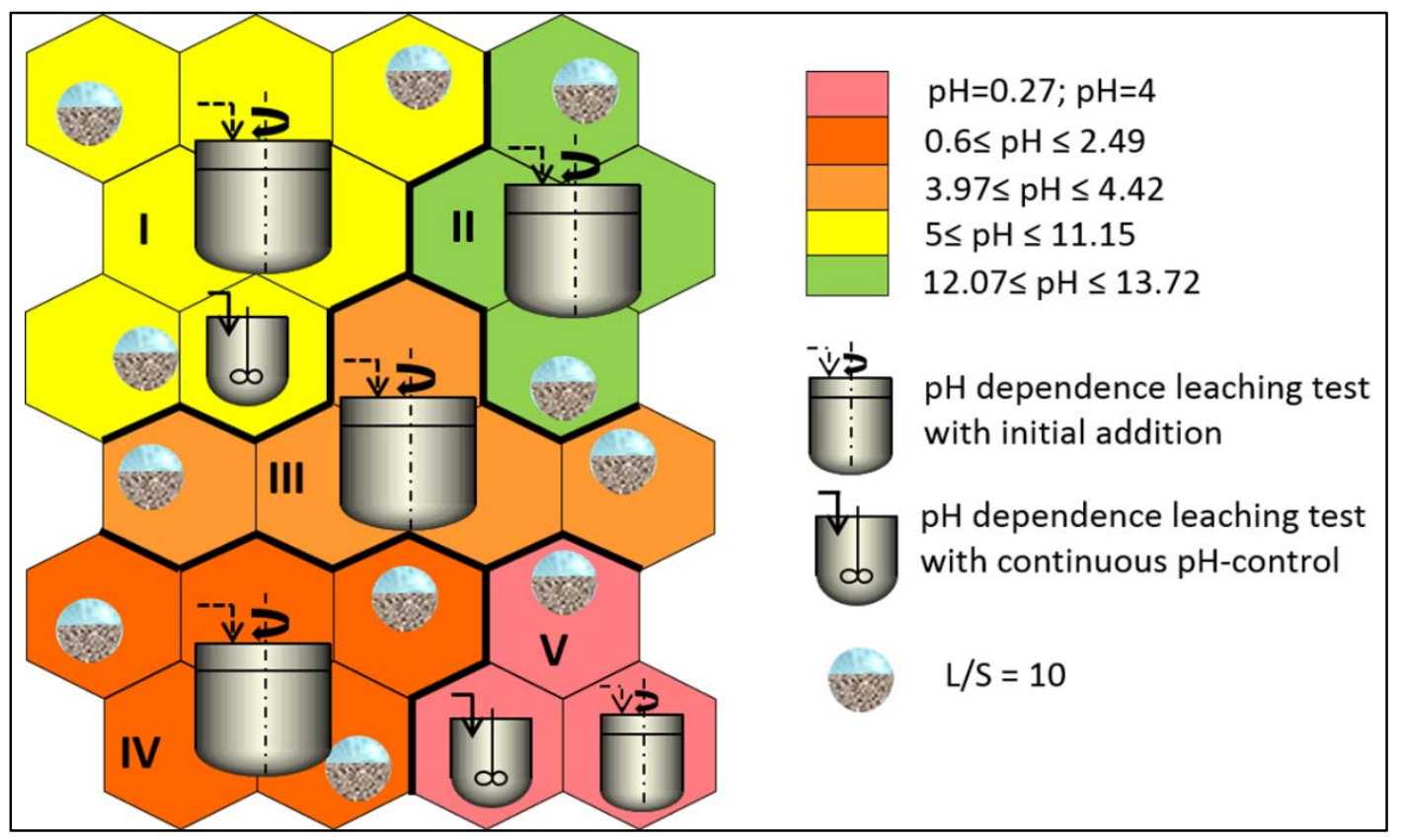

Fig7. Qualitative map for the $\mathrm{pH}$ dependence leaching tests with $\mathrm{HNO}_{3}$ acidification. Clusters are characterized by the $\mathrm{pH}$ (color), and by the leaching contact, represented by reactors; in clusters with both of the reactors, their relative size is identified with the number of samples of each contact in the cluster. The liquid to solid ratio is the same in all clusters $(\mathrm{L} / \mathrm{S}=10)$. 


\title{
Tables
}

\author{
Assessment by Self-Organizing Maps of element-release from sediments in contact with \\ acidified seawater in laboratory leaching test conditions \\ I. Muñoz ${ }^{(1)(*)}$, M.C. Martín-Torre ${ }^{(1)}$, B. Galán ${ }^{(1)}$, J.R. Viguri ${ }^{(1)}$ \\ (1) GER Green Engineering and Resources Group. Department of Chemistry and Process \& Resource \\ Engineering, ETSIIT, University of Cantabria, Spain. \\ ${ }^{(*)}$ Corresponding author: (942)201583, munozi@unican.es
}

TABLE 1. Main characteristics of the LCA and modelling risk assessment tools used for CCS evaluation.

\begin{tabular}{|c|c|c|c|c|}
\hline $\begin{array}{l}\text { Risk assessment } \\
\text { tool applied }\end{array}$ & $\begin{array}{c}\text { Phases of CCS } \\
\text { analyzed }\end{array}$ & $\begin{array}{c}\text { Leakages in } \\
\text { storage phase } \\
\text { taken into } \\
\text { account } \\
\end{array}$ & $\begin{array}{c}\text { Parameters used for } \\
\text { risk assessment as } \\
\text { consequence of } \\
\text { leakages }\end{array}$ & Reference \\
\hline \multirow{16}{*}{ 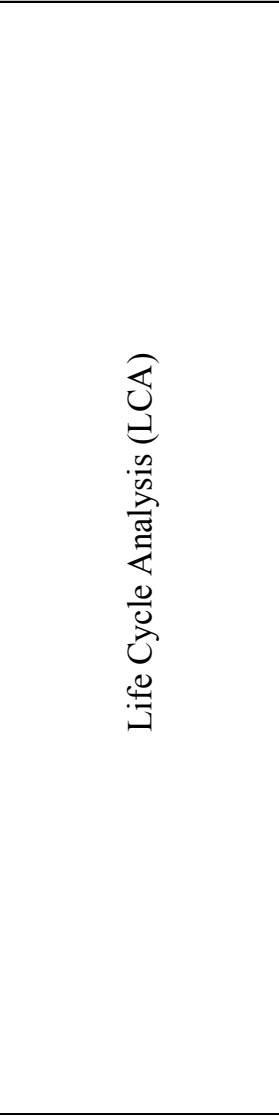 } & $\begin{array}{c}\text { Capture, transport and } \\
\text { storage }\end{array}$ & Yes & Leakage ratio & BMU (2008) \\
\hline & $\begin{array}{c}\text { Capture, transport and } \\
\text { storage }\end{array}$ & No & - & Hertwich et al. (2008) \\
\hline & $\begin{array}{c}\text { Capture, transport and } \\
\text { storage }\end{array}$ & No & - & Pehnt and Henkel (2009) \\
\hline & $\begin{array}{c}\text { Capture, transport and } \\
\text { storage }\end{array}$ & No & - & Nie et al. (2011) \\
\hline & $\begin{array}{c}\text { Capture, transport and } \\
\text { storage }\end{array}$ & No & - & Singh et al. (2011) \\
\hline & $\begin{array}{c}\text { Capture, transport and } \\
\text { storage }\end{array}$ & Yes & Leakage ratio & Hussain et al. (2013) \\
\hline & $\begin{array}{c}\text { Capture, transport and } \\
\text { storage }\end{array}$ & No & - & Iribarren et al. (2013) \\
\hline & Capture \& transport & No & - & Akai et al. (1997) \\
\hline & Capture \& transport & No & - & Nagashima et al. (2011) \\
\hline & Capture \& transport & No & - & Singh et al. (2012) \\
\hline & Capture & No & - & Khoo et al. (2006) \\
\hline & Capture & No & - & Viebahn et al. (2007) \\
\hline & Storage & No & - & Chadwick et al. (2004) \\
\hline & Storage & Yes & $\begin{array}{c}\text { Degradation of } \\
\text { aquifer properties }\end{array}$ & Korre et al. (2009) \\
\hline & Storage & Yes & Leakage ratio & Hou et al. (2012) \\
\hline & Storage & Yes & $\begin{array}{l}\text { Degradation of } \\
\text { aquifer properties }\end{array}$ & Zhou et al. (2013) \\
\hline \multirow{7}{*}{ 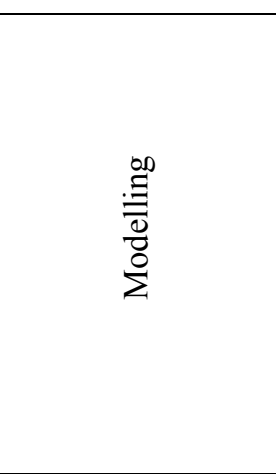 } & \multirow{3}{*}{ Storage } & \multirow{3}{*}{ Yes } & $\begin{array}{c}\text { Alterations on } \\
\text { groundwater }\end{array}$ & \multirow{3}{*}{ Birkholzer et al. (2008) } \\
\hline & & & Metals mobilization & \\
\hline & & & $\mathrm{pH}$ variations & \\
\hline & Transport \& storage & Yes & $\begin{array}{c}\text { Probability of leakage } \\
\text { occurrence }\end{array}$ & Hill et al. (2011) \\
\hline & Storage & Yes & $\begin{array}{c}\text { Degradation of } \\
\text { aquifer properties }\end{array}$ & Keating et al. (2011) \\
\hline & Transportation & No & - & Mazzoldi et al. (2011) \\
\hline & Storage & No & - & Xiao et al. (2009) \\
\hline \multirow{2}{*}{$\begin{array}{l}\text { Modelling and } \\
\text { Simulation }\end{array}$} & Storage & Yes & Leakage ratio & Meyer et al. (2009) \\
\hline & Storage & Yes & $\begin{array}{l}\text { Degradation of } \\
\text { aquifer properties }\end{array}$ & Sakamoto et al. (2011) \\
\hline $\begin{array}{c}\text { Techno-economic } \\
\text { Modelling }\end{array}$ & $\begin{array}{c}\text { Capture, transport and } \\
\text { storage }\end{array}$ & No & - & $\begin{array}{c}\text { Van der Zwaan and } \\
\text { Gerlagh (2009) }\end{array}$ \\
\hline
\end{tabular}


Table 2. Data set of values of the 8 variables in the 60 samples from equilibrium and column leaching tests with $\mathrm{CO}_{2}$ acidified seawater.

\begin{tabular}{|c|c|c|c|c|c|c|c|c|}
\hline \multirow{2}{*}{ SAMPLE } & \multicolumn{8}{|c|}{ VARIABLES $(\mu \mathrm{g} / \mathrm{L})$} \\
\hline & $\mathrm{Cr}$ & $\mathbf{N i}$ & $\mathrm{Cu}$ & $\mathbf{Z n}$ & As & Cd & $\mathbf{P b}$ & DOC $\left(10^{-4}\right)$ \\
\hline Ec5/0.1 & 6.93 & 30.3 & 1370 & 6880 & 3.41 & 1.59 & 43.8 & 6.85 \\
\hline Ec5/0.2 & 7.26 & 35.1 & 1710 & 7890 & 3.20 & 1.31 & 86.8 & 4.70 \\
\hline Ec5/0.5 & 7.15 & 38.6 & 3170 & 9110 & 3.60 & 1.02 & 188 & 2.16 \\
\hline Ec5/1 & 7.21 & 38.6 & 3870 & 9690 & 3.61 & 0.92 & 258 & 1.63 \\
\hline Ec5/2 & 7.37 & 40.0 & 4210 & 10720 & 3.48 & 1.08 & 365 & 1.59 \\
\hline Ec5/4 & 7.66 & 43.6 & 4890 & 11500 & 3.38 & 0.89 & 424 & 1.42 \\
\hline Ec5/5 & 7.77 & 43.2 & 5100 & 11160 & 3.40 & 0.90 & 439 & 1.09 \\
\hline Ec5/10 & 7.98 & 39.0 & 5000 & 9670 & 3.26 & 0.90 & 376 & 1.79 \\
\hline Ec6/0.1 & 6.18 & 11.4 & 399 & 1710 & 9.81 & 0.09 & 24.7 & 5.76 \\
\hline Ec6/0.2 & 6.15 & 9.18 & 296 & 1870 & 9.39 & 0.07 & 14.8 & 3.30 \\
\hline Ec6/0.5 & 6.09 & 8.27 & 215 & 1620 & 8.64 & 0.05 & 8.18 & 2.10 \\
\hline Ec6/1 & 6.06 & 8.58 & 176 & 1430 & 8.43 & 0.05 & 7.34 & 4.58 \\
\hline Ec6/2 & 6.02 & 8.19 & 150. & 1230 & 8.39 & 0.05 & 4.86 & 3.20 \\
\hline Ec6/4 & 5.95 & 8.88 & 138 & 1270 & 8.29 & 0.05 & 4.25 & 0.827 \\
\hline Ec6/5 & 5.90 & 9.18 & 135 & 1230 & 8.33 & 0.06 & 3.91 & 2.67 \\
\hline Ec6/10 & 5.78 & 10.6 & 134 & 792 & 8.20 & 0.06 & 4.08 & 1.00 \\
\hline Ec7/0.1 & 6.04 & 12.5 & 286 & 770 & 15.4 & 0.23 & 8.91 & 2.42 \\
\hline Ec7/0.2 & 6.37 & 10.8 & 241 & 752 & 14.3 & 0.22 & 6.25 & 1.10 \\
\hline Ec7/0.5 & 5.95 & 9.49 & 205 & 754 & 12.9 & 0.14 & 4.02 & 6.18 \\
\hline Ec7/1 & 5.77 & 9.73 & 185 & 890 & 12.0 & 0.13 & 3.30 & 4.10 \\
\hline Ec7/2 & 5.58 & 8.93 & 169 & 731 & 11.4 & 0.09 & 2.86 & 6.65 \\
\hline Ec7/4 & 5.47 & 9.32 & 160 & 792 & 10.4 & 0.08 & 2.29 & 1.69 \\
\hline Ec7/5 & 5.48 & 9.46 & 153 & 818 & 10.2 & 0.08 & 2.11 & 1.40 \\
\hline Ec7/10 & 5.43 & 9.27 & 139 & 611 & 9.28 & 0.06 & 2.23 & 1.73 \\
\hline Ec8/0.1 & 8.66 & 9.76 & 997 & 1100 & 24.6 & 0.12 & 4.68 & 55.9 \\
\hline Ec8/0.2 & 8.45 & 7.98 & 939 & 861 & 22.6 & 0.09 & 3.53 & 40.9 \\
\hline Ec8/0.5 & 7.82 & 6.62 & 840 & 640 & 20.5 & 0.06 & 2.81 & 32.3 \\
\hline Ec8/1 & 7.35 & 5.98 & 723 & 522 & 18.6 & 0.05 & 2.17 & 19.5 \\
\hline Ec8/2 & 6.79 & 5.97 & 582 & 466 & 16.7 & 0.05 & 1.85 & 13.6 \\
\hline Ec8/4 & 6.35 & 5.97 & 437 & 523 & 14.8 & 0.04 & 1.74 & 6.90 \\
\hline Ec8/5 & 6.23 & 5.97 & 395 & 546 & 14.2 & 0.04 & 1.62 & 6.46 \\
\hline Ec8/10 & 6.07 & 5.43 & 305 & 446 & 13.0 & 0.04 & 1.94 & 4.85 \\
\hline
\end{tabular}

Ec a/b: samples from column leaching test $(\mathrm{Ec})$ at $\mathrm{pH}=\mathrm{a}$, and $\mathrm{L} / \mathrm{S}=\mathrm{b}$.

Eeq a/b: samples from equilibrium leaching test (Eeq) at $\mathrm{pH}=\mathrm{a}$, and $\mathrm{L} / \mathrm{S}=\mathrm{b}$. 
Table 2 (Cont.). Data set of values of the 8 variables in the 60 samples from equilibrium and column leaching tests with $\mathrm{CO}_{2}$ acidified seawater.

\begin{tabular}{|c|c|c|c|c|c|c|c|c|}
\hline \multirow{2}{*}{ SAMPLE } & \multicolumn{8}{|c|}{ VARIABLES $(\mu \mathrm{g} / \mathrm{L})$} \\
\hline & $\mathrm{Cr}$ & $\mathrm{Ni}$ & $\mathrm{Cu}$ & $\mathbf{Z n}$ & As & $\mathbf{C d}$ & $\mathbf{P b}$ & $\operatorname{DOC}\left(10^{-4}\right)$ \\
\hline Eeq5/2 & 1.84 & 13.5 & 64.7 & 355 & 6.92 & 1.45 & 8.30 & 8.90 \\
\hline Eeq5/4 & 4.74 & 42.1 & 25.0 & 124 & 13.4 & 1.50 & 9.38 & 6.58 \\
\hline Eeq5/10 & 1.48 & 339.6 & 121 & 69.5 & 13.0 & 1.90 & 8.35 & 7.78 \\
\hline Eeq5/15 & 83.7 & 4.11 & 13.8 & 9.72 & 15.0 & 0.06 & 0.44 & 1.38 \\
\hline Eeq5/20 & 104 & 4.09 & 15.0 & 9.86 & 18.0 & 0.01 & 0.33 & 0.740 \\
\hline Eeq5/30 & 34.0 & 8.27 & 67.8 & 257 & 12.0 & 0.04 & 2.10 & 0.810 \\
\hline Eeq5/40 & 40.0 & 6.14 & 85.7 & 17.4 & 11.0 & 0.06 & 5.00 & 0.310 \\
\hline Eeq6/2 & 11.2 & 18.4 & 1290 & 580 & 34.4 & 0.26 & 4.74 & 3.99 \\
\hline Eeq6/4 & 7.29 & 14.5 & 844 & 157 & 34.4 & 0.07 & 8.57 & 3.74 \\
\hline Eeq6/15 & 85.1 & 2.10 & 13.2 & 11.3 & 10.0 & 0.23 & 0.81 & 0.98 \\
\hline Eeq6/10 & 5.42 & 22.0 & 191 & 578 & 15.3 & 0.13 & 5.72 & 3.72 \\
\hline Eeq6/20 & 109 & 2.18 & 20.4 & 1.19 & 13.0 & 0.03 & 0.17 & 0.82 \\
\hline Eeq6/30 & 35.9 & 3.65 & 268 & 60.9 & 5.12 & 0.03 & 2.43 & 0.52 \\
\hline Eeq6/40 & 42.5 & 2.64 & 162 & 8.12 & 6.09 & 0.01 & 1.73 & 0.19 \\
\hline Eeq7/2 & 13.3 & 3.53 & 1180 & 31.7 & 32.0 & 0.15 & 1.99 & 6.47 \\
\hline Eeq7/4 & 9.39 & 28.7 & 1320 & 153 & 33.8 & 0.08 & 2.39 & 4.21 \\
\hline Eeq7/10 & 6.17 & 4.20 & 272.2 & 46.2 & 17.4 & 0.13 & 1.66 & 2.89 \\
\hline Eeq7/15 & 86.8 & 1.73 & 12.1 & 2.61 & 9.16 & 0.10 & 0.11 & 1.25 \\
\hline Eeq7/20 & 115.0 & 2.05 & 8.49 & 0.90 & 13.2 & 0.09 & 0.09 & 1.07 \\
\hline Eeq7/30 & 32.01 & 2.68 & 250 & 39.6 & 3.94 & 0.01 & 0.87 & 0.61 \\
\hline Eeq7/40 & 36.38 & 2.09 & 336 & 17.1 & 4.65 & 0.01 & 0.79 & 0.28 \\
\hline Eeq8/2 & 14.6 & 2.35 & 1000 & 23.8 & 31.7 & 0.22 & 0.88 & 23.3 \\
\hline Eeq8/4 & 11.2 & 2.38 & 1400 & 27.5 & 32.5 & 0.11 & 0.64 & 15.0 \\
\hline Eeq8/10 & 7.31 & 2.57 & 454 & 23.7 & 20.1 & 0.16 & 0.75 & 12.7 \\
\hline Eeq8/15 & 90.1 & 1.70 & 11.2 & 6.66 & 9.50 & 0.04 & 0.43 & 1.52 \\
\hline Eeq8/20 & 115.3 & 1.94 & 9.24 & 0.20 & 13.0 & 0.02 & 0.47 & 0.95 \\
\hline Eeq8/30 & 38.0 & 2.69 & 352 & 18.3 & 4.81 & 0.02 & 2.73 & 0.45 \\
\hline Eeq8/40 & 45.4 & 1.55 & 554 & 3.39 & 5.29 & 0.04 & 2.29 & 0.19 \\
\hline
\end{tabular}

Ec a/b: samples from column leaching test $(\mathrm{Ec})$ at $\mathrm{pH}=\mathrm{a}$, and $\mathrm{L} / \mathrm{S}=\mathrm{b}$.

Eeq a/b: samples from equilibrium leaching test (Eeq) at $\mathrm{pH}=\mathrm{a}$, and $\mathrm{L} / \mathrm{S}=\mathrm{b}$. 
Table 3. Data set of values of the 8 variables in the 24 samples from $\mathrm{pH}$ dependence leaching tests with $\mathrm{HNO}_{3}$ acidified seawater.

\begin{tabular}{|c|c|c|c|c|c|c|c|c|}
\hline \multirow{2}{*}{ SAMPLE } & \multicolumn{8}{|c|}{ VARIABLE $(\mu \mathrm{g} / \mathrm{L})$} \\
\hline & $\mathrm{Cr}$ & $\mathbf{N i}$ & $\mathbf{C u}$ & Zn & As & Cd & $\operatorname{Pb}\left(10^{-4}\right)$ & $\operatorname{DOC}\left(10^{-4}\right)$ \\
\hline Ed0.27/10 & 1290 & 732 & 116 & 257450 & 51.9 & 547 & 2.66 & 13.7 \\
\hline Ed0.6/10 & 1280 & 720 & 24.2 & 243870 & 36.1 & 439 & 0.428 & 11.9 \\
\hline Ed0.98/10 & 1270 & 724 & 8.93 & 238520 & 37.8 & 242 & 0.224 & 12.2 \\
\hline Ed1.3/10 & 1140 & 809 & 24.5 & 188740 & 37.0 & 101 & 0.204 & 11.7 \\
\hline Ed2.49/10 & 536 & 506 & 6.62 & 127710 & 71.2 & 18.5 & 0.134 & 10.5 \\
\hline Ed3.97/10 & 130 & 426 & 23.0 & 48640 & 560 & 10.8 & 0.193 & 5.02 \\
\hline Ed4.42/10 & 13.4 & 388 & 15.9 & 36060 & 593 & 4.31 & 0.285 & 4.23 \\
\hline Ed5.32/10 & 2.68 & 170 & 2.45 & 7950 & 24.3 & 1.65 & 0.019 & 3.27 \\
\hline Ed6.51/10 & 1.52 & 47.7 & 1.89 & 506 & 14.9 & 0.33 & 0.001 & 3.08 \\
\hline Ed7.41/10 & 6.82 & 2.79 & 2.76 & 23.1 & 9.98 & 1.16 & 0.001 & 1.80 \\
\hline Ed7.49/10 & 20.3 & 6.01 & 11.7 & 111 & 8.76 & 0.82 & 0.000 & 1.62 \\
\hline Ed8.26/10 & 7.32 & 12.6 & 4.23 & 873 & 12.0 & 1.36 & 0.002 & 3.13 \\
\hline Ed9.44/10 & 1.62 & 8.33 & 1.52 & 30.1 & 15.5 & 0.34 & 0.000 & 3.59 \\
\hline Ed10.73/10 & 43.6 & 84.9 & 12.8 & 2278 & 55.6 & 3.72 & 0.004 & 10.9 \\
\hline Ed11.15/10 & 5.70 & 78.64 & 82.0 & 160 & 81.7 & 1.24 & 0.004 & 14.7 \\
\hline Ed12.07/10 & 12.0 & 58.3 & 16.2 & 54.5 & 469 & 0.44 & 0.001 & 20.5 \\
\hline Ed12.18/10 & 13.8 & 99.2 & 28.2 & 362 & 1260 & 0.31 & 0.006 & 38.9 \\
\hline Ed13.72/10 & 35.9 & 105 & 23.6 & 580 & 1360 & 1.35 & 0.008 & 36.0 \\
\hline Edc4/10 & 8.73 & 373 & 27.6 & 210180 & 148 & 506 & 1.95 & 4.01 \\
\hline Edc5/10 & 1.01 & 282 & 2.45 & 93220 & 14.7 & 43.8 & 0.155 & 2.27 \\
\hline Edc5.5/10 & 1.27 & 228 & 1.80 & 51450 & 15.0 & 14.4 & 0.040 & 1.74 \\
\hline Edc6/10 & 2.23 & 118 & 2.58 & 12230 & 4.39 & 3.02 & 0.011 & 0.999 \\
\hline Edc6.5/10 & 1.03 & 35.9 & 3.73 & 1370 & 3.31 & 0.24 & 0.002 & 1.56 \\
\hline Edc7/10 & 0.66 & 12.8 & 2.07 & 283 & 2.21 & 0.19 & 0.001 & 0.642 \\
\hline
\end{tabular}

$\mathrm{Ed} \mathrm{a} / \mathrm{b}$ : samples from $\mathrm{pH}$ dependence leaching test with initial addition (Ed) at $\mathrm{pH}=\mathrm{a}$, and $\mathrm{L} / \mathrm{S}=\mathrm{b}$.

$\mathrm{Edc} \mathrm{a} / \mathrm{b}$ : samples from $\mathrm{pH}$ dependence leaching test with continuous $\mathrm{pH}$-control $(\mathrm{Edc})$ at $\mathrm{pH}=\mathrm{a}$, and $\mathrm{L} / \mathrm{S}=\mathrm{b}$.

TABLE 4. Quality measures (quantization error (QE) and topographic error (TE)) of the SOMs of different map sizes obtained with three normalizations of the data $(n=60)$.

\begin{tabular}{|c|c|c|c|c|c|c|}
\hline \multirow{2}{*}{ Map Size } & \multicolumn{2}{|c|}{ Normalization LOG } & \multicolumn{2}{c|}{ Normalization RANGE } & \multicolumn{2}{c|}{ Normalization VAR } \\
\cline { 2 - 7 } & $Q E$ & $T E$ & $Q E$ & $T E$ & $Q E$ & $T E$ \\
\hline $6 \times 6=36$ & 1.294 & 0 & 0.152 & 0.05 & 0.705 & 0.017 \\
\hline $7 \times 5=35$ & 1.323 & 0.033 & 0.153 & 0.017 & 0.666 & 0.017 \\
\hline $7 \times 6=42$ & 1.198 & 0.017 & 0.143 & 0 & 0.610 & 0.017 \\
\hline $7 \times 7=49$ & 1.102 & 0.017 & 0.119 & 0 & 0.527 & 0.05 \\
\hline $8 \times 5=40$ & 1.191 & 0.017 & 0.138 & 0 & 0.649 & 0 \\
\hline $8 \times 6=48$ & 1.091 & 0.017 & 0.121 & 0.017 & 0.532 & 0.033 \\
\hline $9 \times 4=36$ & 1.249 & 0.033 & 0.154 & 0 & 0.684 & 0.017 \\
\hline 9X5=45 & 1.122 & 0.033 & 0.129 & 0.033 & 0.563 & 0.017 \\
\hline
\end{tabular}


TABLE 5. Quality measures (quantization error (QE) and topographic error (TE)) of the SOMs of different map sizes obtained with three normalizations of the data $(n=24)$.

\begin{tabular}{|c|c|c|c|c|c|c|}
\hline \multirow{2}{*}{ Map Size } & \multicolumn{2}{|c|}{ Normalization LOG } & \multicolumn{2}{c|}{ Normalization RANGE } & \multicolumn{2}{c|}{ Normalization VAR } \\
\cline { 2 - 7 } & $Q E$ & $T E$ & $Q E$ & $T E$ & $Q E$ & $T E$ \\
\hline $5 \times 4=20$ & 2.556 & 0 & 0.257 & 0 & 0.915 & 0 \\
\hline $5 \times 5=25$ & 2.342 & 0 & 0.231 & 0 & 0.865 & 0.042 \\
\hline $6 \times 4=24$ & 2.331 & 0 & 0.225 & 0 & 0.796 & 0 \\
\hline $6 \times 5=30$ & 2.103 & 0.042 & 0.204 & 0 & 0.691 & 0 \\
\hline $7 \times 3=21$ & 2.444 & 0 & 0.231 & 0.042 & 0.79 & 0 \\
\hline $7 \times 4=28$ & 2.148 & 0 & 0.196 & 0 & 0.697 & 0 \\
\hline $8 \times 3=24$ & 2.181 & 0 & 0.223 & 0.083 & 0.771 & 0.083 \\
\hline
\end{tabular}

